\title{
Phytoplankton morphology controls on marine snow sinking velocity
}

\author{
Emmanuel C. Laurenceau-Cornec ${ }^{1,2,3, *}$, Thomas W. Trull ${ }^{2,3}$, Diana M. Davies ${ }^{2}$, \\ Christina L. De La Rochaa ${ }^{4}$, Stéphane Blain ${ }^{5,6}$ \\ ${ }^{1}$ Institute for Marine and Antarctic Studies, University of Tasmania, Private Bag 129, Hobart, Tasmania 7001, Australia \\ ${ }^{2}$ Antarctic Climate and Ecosystems Cooperative Research Centre, University of Tasmania, Private Bag 80, Hobart, \\ Tasmania 7001, Australia \\ ${ }^{3}$ Commonwealth Scientific and Industrial Research Organisation, Marine and Atmospheric Research, Castray Esplanade, \\ Hobart, Tasmania 7000, Australia \\ ${ }^{4}$ CNRS, UMR 6539, Institut Universitaire Européen de la Mer, Université de Bretagne Occidentale, Technopôle Brest-Iroise, \\ Rue Dumont d'Urville, Plouzané 29280, France \\ ${ }^{5}$ CNRS and ${ }^{6}$ UPMC Université Paris 06, UMR 7621, LOMIC, Observatoire Océanologique, Banyuls-sur-Mer 66650, France
}

\begin{abstract}
During the second KErguelen Ocean and Plateau compared Study (KEOPS2) in October-November 2011, marine snow was formed in roller tanks by physical aggregation of phytoplankton assemblages sampled at 6 stations over and downstream of the Kerguelen Plateau. Sinking velocities, morphology, bulk composition (transparent exopolymer particles, biogenic silica, particulate organic carbon), and phytoplankton contents were measured individually on 66 aggregates to identify controls on sinking velocities. Equivalent spherical diameters (ESD) ranged from 1 to $12 \mathrm{~mm}$, and the particle aspect ratios, Corey shape factors, and fractal dimensions $\left(D_{\mathrm{F} 1}=\right.$ $\left.1.5, D_{\mathrm{F} 2}=1.8\right)$ were close to those of smaller natural aggregates $(0.2$ to $1.5 \mathrm{~mm})$ collected in polyacrylamide gel-filled sediment traps $\left(D_{\mathrm{F} 1}=1.2, D_{\mathrm{F} 2}=1.9\right)$. Sinking velocities ranged between 13 and $260 \mathrm{~m} \mathrm{~d}^{-1}$, and were correlated with aggregate size only when considering individually the experiments conducted at each station, suggesting that a site-dependent control prevailed over the general influence of size. Variation in dominant diatom morphologies among the sites (classified as small spine-forming or chain without spines) appeared to be a determinant parameter influencing the sinking velocity (SV $\left[\mathrm{m} \mathrm{d}^{-1}\right]=168-1.48 \times(\%$ small spine-forming cells $\left.), r^{2}=0.98\right)$, possibly via a control on species-specific coagulation efficiency affecting particle structure and excess density. Our results emphasize the importance of ecological considerations over that of simple compositional perspectives in the control of particle formation, and in accurate parameterizations of marine snow sinking velocities that are essential to predictions of biological carbon sequestration.
\end{abstract}

KEY WORDS: Sinking velocity $\cdot$ Marine snow $\cdot$ Aggregation $\cdot$ Phytoplankton $\cdot$ Porosity Resale or republication not permitted without written consent of the publisher

\section{INTRODUCTION}

In the ocean, the rain of large biogenic particles is a major pathway for the export of carbon from the surface to the interior (Suess 1980, Fowler \& Knauer 1986, Asper et al. 1992). This mechanism contributes significantly to the drawdown of atmospheric carbon dioxide, and has become known as the 'oceanic biological carbon pump' (Volk \& Hoffert 1985). Substantial production of particulate organic matter (POM) in the euphotic zone is essential but not sufficient to obtain high carbon export (Buesseler 1998). The speed at which particles settle is also a critical parameter since it determines the duration of their expo- 
sure to extensive physical and biological transformations (Karl et al. 1988, Boyd et al. 1999) responsible for the observed attenuation of the particle flux with depth (Martin et al. 1987, Silver \& Gowing 1991).

In the Southern Ocean, a region known to play a leading role in global climate and carbon systems (Sigman \& Boyle 2000), primary productivity is low due to phytoplankton growth restriction by a combination of iron and light limitation (Martin 1990, de Baar et al. 1995). These waters are described as 'high nutrient, low chlorophyll' (HNLC), and contain a large amount of unused surface macronutrients capable of fuelling the production of high quantities of organic carbon and potentially its sequestration. Against this background, like oases in deserts, some areas in the Southern Ocean are fertilized by a natural supply of iron and display remarkable seasonal biomass increases (Sullivan et al. 1993), offering a great opportunity to investigate the controls on carbon export efficiencies in the context of iron fertilization.

This study focuses on the bloom that occurs each year between October and February over and downstream of the Kerguelen Plateau in the Indian sector of the Southern Ocean (Blain et al. 2007). In January-February 2005, the first KErguelen Ocean and Plateau compared Study (KEOPS1) demonstrated that the downward flux of carbon was elevated by a factor of 2 to 3 in comparison to the surrounding HNLC waters (Savoye et al. 2008). Particle size spectra from an in situ camera demonstrated that more and larger particles were present beneath the bloom (to $400 \mathrm{~m}$ depth) than in surrounding HNLC waters, although a comparison to size spectra of particles collected in gel-filled sediment traps showed slower sinking velocities (Jouandet et al. 2011), suggesting that sinking velocity was not a simple monotonic function of particle size.

According to theory and empirical studies, size is known to exert a major control on particle sinking velocity (Dietrich 1982, Gibbs 1985), but discrepancies in the size-sinking velocity relationship are often reported, and other parameters (e.g. particle composition or structure) can prevail over size in the control of the sinking velocity, as previously noted (Diercks \& Asper 1997, Engel \& Schartau 1999, Iversen \& Ploug 2010). While extensive study of these parameters has verified their importance, it has also turned out to be difficult to define a limited number of parameters suitable to predict carbon export accurately-something that would be of considerable use in computationally expensive models of ocean biogeochemical cycling. Among these parameters, the shape (McNown \& Malaika 1950, Alldredge \& Gotschalk 1988), porosity or compactness (Kajihara 1971, Iversen \& Ploug 2010), permeability (Matsumoto \& Suganuma 1977), fractal structure (Johnson et al. 1996, Engel et al. 2009), content of high density minerals (Armstrong et al. 2001, Klaas \& Archer 2002, Passow \& De La Rocha 2006) or low density particulate polysaccharides (Engel \& Schartau 1999, Azetsu-Scott \& Passow 2004), phytoplankton species (Passow 1991, Padisák et al. 2003) and their physiological state (Bienfang et al. 1982, Waite et al. 1992, Muggli et al. 1996) or individual organism size (Boyd \& Newton 1995, Waite et al. 1997a) have been proposed as potential controls of particle sinking velocity. Due to this high complexity and the absence of clear controlling factors provided by empirical research, most biogeochemical models have no other alternative than simple sinking velocity parameterization (e.g. constant or size-dependent). Several modelling studies have focused on the sensitivity to sinking velocity parameterization, testifying to the awareness that improvements are needed and that more complexity needs to be added to the models (Gehlen et al. 2006, Kriest \& Oschlies 2008, 2013, Losch et al. 2014). Here, we investigate a comprehensive set of morphological and compositional parameters in a single study to identify potential influences on particle sinking velocity and to develop a possible explanation for the inconsistencies often observed between sinking velocity and particle size, offering a potential alternative for biogeochemical model parameterization.

\section{Theory}

We refer the reader to the classic textbook on fluid dynamics from Batchelor (1967) for further details on the theory of particle sinking velocity.

For a sphere settling in a fluid, the immersed weight $\left(W_{\mathrm{i}}\right)$ is the difference between the force of gravity acting downward and the buoyancy force acting upward, and is given by (e.g. Komar \& Reimers 1978):

$$
W_{\mathrm{i}}=\frac{\pi}{6} D^{3}\left(\rho_{\mathrm{s}}-\rho_{\mathrm{f}}\right) g
$$

where $D$ is the diameter of the sphere, $\rho_{\mathrm{s}}$ and $\rho_{\mathrm{f}}$ are the sphere and fluid densities, respectively, and $g$ (9.81 $\mathrm{m} \mathrm{s}^{-2}$ ) is the acceleration due to gravity. The

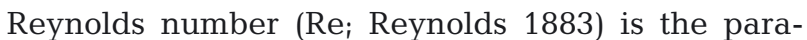
meter that determines a flow field for boundaries of a given form and is given by: 


$$
\operatorname{Re}=\frac{U_{\mathrm{s}} D}{\mathrm{v}}
$$

where $U_{\mathrm{s}}$ is the sphere sinking velocity and $v$ is the kinematic viscosity of the fluid.

Particles termed 'marine snow' are large aggregates $(>0.5 \mathrm{~mm})$ formed by physical aggregation of phytoplankton and miscellaneous debris: mostly fecal pellets, inorganic particles and zooplankton feeding structures (Alldredge \& Silver 1988, Alldredge \& Gotschalk 1990). Because of their large size and potentially high sinking velocity (Alldredge \& Silver 1988), the settling of marine snow aggregates in the water column occurs at $\operatorname{Re}>0.5$ (Alldredge \& Gotschalk 1988). In these conditions the drag force $F_{\mathrm{D}}$ is proportional to the square of the velocity:

$$
F_{\mathrm{D}}=C_{\mathrm{D}} A \frac{\rho_{\mathrm{f}} U_{\mathrm{agg}}^{2}}{2}
$$

where $U_{\text {agg }}$ is the sinking velocity of the aggregate, $C_{\mathrm{D}}$ is the drag coefficient (an empirical proportionality coefficient between $F_{\mathrm{D}}$ and $U^{2}{ }_{\text {agg }}$ ) and $A$ is the projected area of the aggregate in the direction of motion. At terminal velocity, the drag force is balanced by the immersed weight giving a force balance equation which, after algebraic manipulations, leads to a general expression for the sinking velocity:

$$
U_{\mathrm{agg}}=\left[\frac{4}{3} \frac{g(\Delta \rho) D}{C_{\mathrm{D}} \rho_{\mathrm{sw}}}\right]^{1 / 2}
$$

where $\Delta \rho$ is the aggregate excess density calculated as the difference between aggregate density and seawater density $\left(\rho_{\mathrm{sw}}\right)$. In this equation, applicable to all Reynolds numbers, the drag coefficient is a complex function of both aggregate shape and Reynolds number. For simplicity, we refer to Eq. (4) as the 'general sinking velocity model' in the rest of the text.

Considering a small perfect sphere settling through a quiescent fluid and assuming that the inertial forces are negligible compared to viscous forces, G. G. Stokes solved in December 1850 the low Reynolds number limit of the Navier-Stokes equations (Stokes 1851), and obtained a simplified expression of the drag force:

$$
F_{\mathrm{D}}=3 \pi \mu D U_{\mathrm{s}}
$$

where $\mu$ is the dynamic viscosity of the fluid. Again, at terminal velocity, the immersed weight equals the drag force yielding the Stokes expression:

$$
U_{\mathrm{s}}=\frac{1}{18} \frac{g\left(\rho_{\mathrm{s}}-\rho_{\mathrm{f}}\right) D^{2}}{\mu}
$$

In this expression, the properties of the sphere influencing its settling velocity are only the density and the diameter. Because of the assumptions made by Stokes, Eqs. (5) \& (6) are only valid at small Reynolds number, empirically found to apply to Re $<0.5$ (Graf \& Acaroglu 1966, White 1974, Komar \& Reimers 1978).

By comparing the general model (Eq. 4) to its particular case represented by the Stokes' expression (Eq. 6), one can notice that the settling velocity has a weaker dependence on size in the general model since the diameter is raised to the power of 0.5 , rather than 2 as in the Stokes' law.

In Fig. 1 we plot various empirical and theoretical data of sinking velocity versus size for marine snow, from the present study and others using different methods and approaches. Since these studies were carried out over a range of different water temperatures and salinities, we investigated whether temperature and salinity variations could contribute significantly to sinking velocity variations through their influence on seawater dynamic viscosity $(\mu)$ and density $\left(\rho_{\mathrm{sw}}\right)$. Stokes' law predicts that, at a fixed aggregate porosity and solid content density (e.g. 99\% porosity and $\rho_{\mathrm{sol}}=1170 \mathrm{~kg} \mathrm{~m}^{-3}$, corresponding to $30 \%$ transparent exopolymeric particles [TEP], $20 \%$ biogenic silica [BSi], and $50 \%$ particulate organic matter $[\mathrm{POM}]$ in solid content), a temperature increase from 2 to $20^{\circ} \mathrm{C}$ or a salinity decrease from 34 to 2 would lead respectively to a 40 and $20 \%$ increase in the sinking velocity. It is very likely that the differences between the studies did not exceed these very large range of temperature and salinity variations, and given that Fig. 1 is a $\log -\log$ plot, the effect of temperature and salinity changes on the sinking velocity can reasonably be neglected here.

Overall, the data suggest a relatively weak dependence of sinking velocity on particle size both when considering the whole dataset or each study separately. The general model gives to size a weaker control on sinking velocity and a stronger dependence on drag and excess density influenced by particle structure and composition; our calculations show that the general model provides a better representation of the observations for large particles than the usual Stokes' law (Fig. 1). In combination with porosity increasing with size according to a fractal scaling known to apply to marine snow, and using the formula proposed by Logan \& Wilkinson (1990; see 'Materials and methods: Measurement of aggregate morphology and structure'), the general model shows poor size-sinking velocity correlation for the large particle size range (Fig. 1, line 2). Based on this, it appears that particle structure, morphology and composition could prevail over size in the control of sinking velocity via a control on particle drag and excess density. 


\section{Particle type - Method used}

- Marine snow from natural phyto. assemblages - Roller tank, settling column

+ Diatom culture agg. - Roller tank, video recording

$\triangle$ Natural agg. - Gel trap and in situ imaging

- Carbonate-ballast culture agg. - Roller tank, vertical flow, video recording

- Opal-ballast culture agg. - Roller tank, vertical flow, video recording

* Natural agg. - Gel trap and in situ imaging

$\times$ Natural marine snow - In situ settling chamber, Cherokee ROV

- Natural marine snow - In situ (MASCOT)

$\square \quad$ River flocs - In situ Floc Camery Assembly

$\checkmark$ Natural agg. - In lab., linear density gradient column

$\checkmark$ Diatom culture agg. - In lab., linear density gradient column

$\square \quad$ Natural marine snow - SCUBA diving

- Estuarine flocs - Settling tank

$\square$ Natural agg. - In situ holographic measurements

+ Natural marine snow - Settling chamber

Recoagulated marine snow - KUROSHIO II submarine

\section{Location}

$\mathrm{n} / \mathrm{a}$

Kerguelen region (Southern Ocean)

$\mathrm{n} / \mathrm{a}$

$\mathrm{n} / \mathrm{a}$

West Antarctic peninsula

Cape Blanc (Mauritania)

Central Black Sea

Halifax river estuary (Nova Scotia)

Bedford basin (Nova Scotia)

$\mathrm{n} / \mathrm{a}$

Santa Barbara Channel (S. California) Chesapeake bay (Maryland)

Western North Atlantic

Monterey bay (Calif.) and NE Atlantic Off Muroran (Japan)

\section{Source}

This study

Laurenceau-Cornec et al. (unpubl.)

Jouandet et al. (2011)

Iversen \& Ploug (2010)

Iversen \& Ploug (2010)

McDonnell \& Buesseler (2010)

Nowald et al. (2009)

Diercks \& Asper (1997)

Syvitski et al. (1995)

Azetsu-Scott \& Johnson (1992)

Azetsu-Scott \& Johnson (1992)

Alldredge \& Gotschalk (1988)

Gibbs (1985)

Carder et al. (1982)

Shanks \& Trent (1980)

Kajihara (1971)

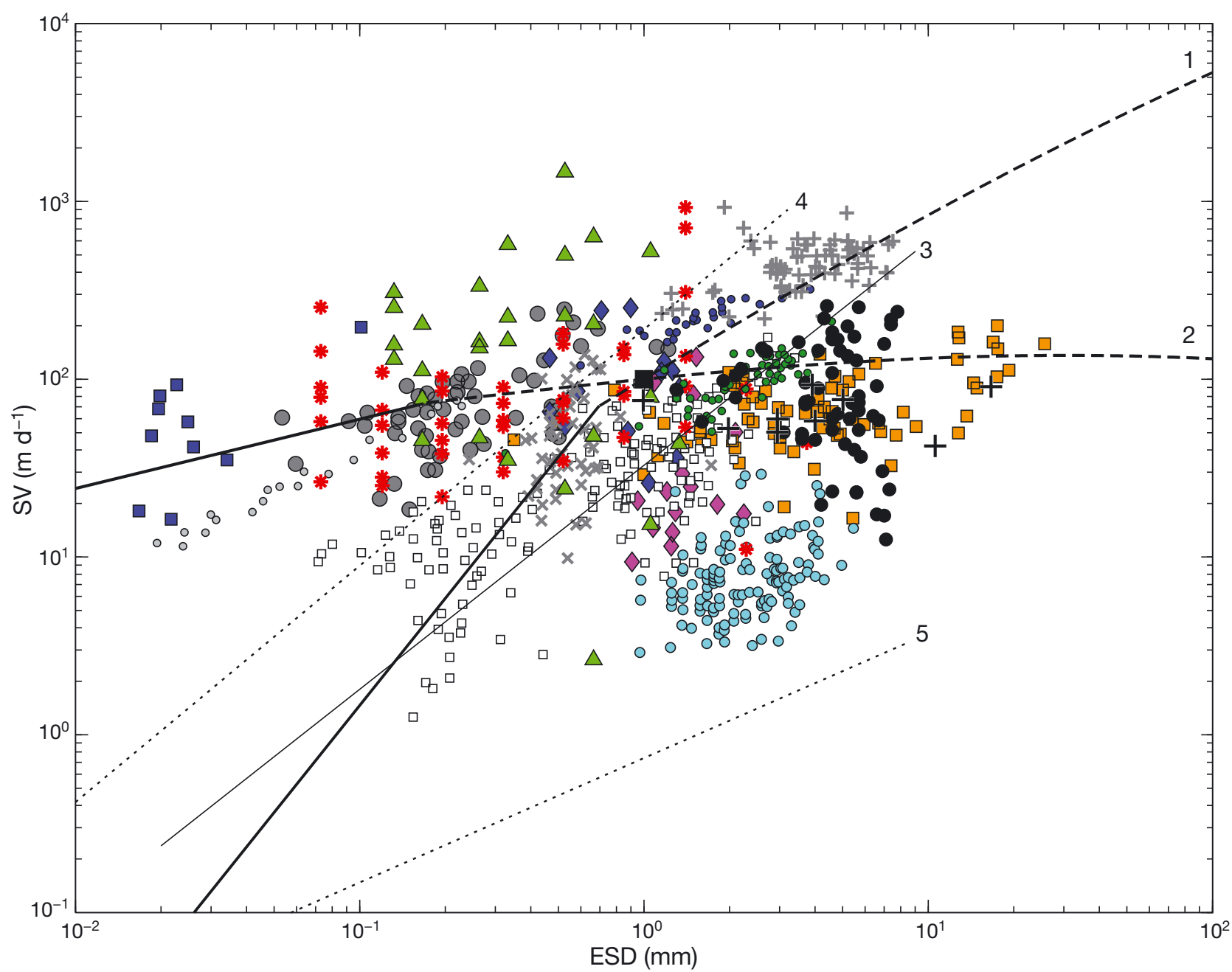

Fig. 1. Sinking velocity (SV) of large marine aggregates (agg.) versus their equivalent spherical diameter (ESD) for this study and others. Theoretical lines and empirical relationships using different approaches are also represented. 1: Stokes' law (Eq. 6) (solid line) and general sinking velocity model (Eq. 4) (dashed line) applying to distinct ranges of Reynolds number for solid body particles with constant excess density $\left(\Delta \rho=0.0014 \mathrm{~g} \mathrm{~cm}^{-3}\right)$; large black square: specific conditions of the models, fixing the initial drag characteristics of the particle $\left(\mathrm{ESD}_{0}=1 \mathrm{~mm}\right.$ and $\left.\mathrm{SV}_{0}=100 \mathrm{~m} \mathrm{~d}^{-1}\right)$. 2: Same models with excess density scaled on a typical fractal geometry for marine snow $\left(D_{\mathrm{F} 3}=1.39, a=0.03\right.$; Logan \& Wilkinson 1990) (see Fig. 3 and 'Results: Sinking velocity' for details). 3: Guidi et al. (2008). 4-5: SV calculated using the coagulation model from Stemmann et al. (2004) with different parameter values (4: excess density $\Delta \rho=0.08$, fractal number $D_{\mathrm{F} 3}=2.33 ; 5: \Delta \rho=0.01, D_{\mathrm{F} 3}=1.79$ ), Phyto.: phytoplankton; Calif.: California; n/a: not applicable 
Aggregate morphological and structural properties likely to control excess density and drag are numerous, and the combined effects of these 2 parameters make their relative influence on the measured sinking velocity hard to distinguish. The drag experienced by a particle might be the result of several parameters, including shape, permeability, and surface roughness, while excess density depends on aggregate composition and compactness (i.e. porosity). The influence of macroscopic shape, permeability, and surface roughness on the sinking velocity have been investigated in the theoretical, experimental, and engineering fields, on natural and artificial particles, but these parameters have generally been described as poor contributors to the sinking velocity (Williams 1966, Achenbach 1974, Matsumoto \& Suganuma 1977, Baba \& Komar 1981, Alldredge \& Gotschalk 1988, Li \& Logan 2001, Li \& Yuan 2002).

The excess density of a marine snow aggregate depends on the density and volume fraction of its solid components (mostly phytoplankton cells in the case of diatom marine snow) and how tightly they are assembled, giving more or less inner space filled by seawater, defined as the porosity (e.g. De La Rocha \& Passow 2007). To our knowledge the species-specific effect of phytoplankton on the alteration of the sizesinking velocity relationship of marine snow aggregates has not been studied to date. We tested here the possible combined effects of varying phytoplankton assemblages on aggregate sinking velocity via ballast effect (Engel et al. 2009) and control on aggregate structure, assuming species-specific aggregate compactness, based on aggregation experiments of phytoplankton cultures (Iversen \& Ploug 2010).

\section{Experimental setup}

We focused on marine snow aggregates, a major component of the vertical flux of organic carbon (Fowler \& Knauer 1986). They represented the main numerical fraction of the flux during KEOPS1 (Ebersbach \& Trull 2008) and KEOPS2 (Laurenceau et al. 2014), and could represent an efficient way to export carbon over the Kerguelen Plateau if they sink rapidly enough to reach the deep ocean before being consumed or remineralized. Because it is difficult to record in situ the sinking velocity of natural marine snow (Alldredge \& Silver 1988), we took an experimental approach. Marine snow aggregates were formed in rotating cylindrical tanks following the method developed by Shanks \& Edmonson (1989). In contrast to the majority of roller tank experiments using phytoplankton cultures, we incubated various natural mixtures of phytoplankton sampled carefully from Niskin bottles to produce aggregates as close as possible to those forming in the water column at different sites. This 'roller tank' technique allows the particles to sink continuously as they would in the water column, and thus to aggregate mainly by differential settling (after a short period of shear during the initiation of solid-body rotation), in which fast-sinking particles scavenge suspended and slower-sinking particles. Thus, the technique minimizes the influences of the 2 other main mechanisms forming marine snow in natural environments: (1) shear, which can also cause disaggregation, and (2) brownian motion, which dominates the collision rate for small $(<1 \mu \mathrm{m})$ particles (McCave 1984, Burd \& Jackson 2009).

Once macroscopic aggregates had formed, they were photographed and their sinking velocities measured. Bulk chemical compositions were determined and the abundances of organisms within the aggregates were examined using light microscopy. To test our hypothesis, all aggregate properties needed to be explored as potential controls of the sinking velocity. Data were thus evaluated in terms of morphological, chemical and biological relative influences on the sinking velocity.

To evaluate the oceanic applicability of the results determined in the roller tank experiments, we compared our aggregates with natural aggregates collected at the same time using polyacrylamide gelfilled sediment traps which allow the sampling of intact particles as they exist in the water column (Jannasch et al. 1980, Ebersbach \& Trull 2008, Laurenceau et al. 2014).

\section{MATERIALS AND METHODS}

\section{Study site and sampling}

This work was conducted during the second KErguelen Ocean and Plateau compared Study (KEOPS2) onboard the RV 'Marion Dufresne' from 8 October to 30 November 2011, over and downstream of the Kerguelen Plateau. One of the major purposes was to characterize the downward particle flux by the use of sediment traps and identify the physical and biological controls on the efficiency of carbon export.

In the present work, duplicate sampling was conducted at 6 stations (Fig. 2) at surface (20 and $30 \mathrm{~m}$ ) and deeper layers $(65,80$ and $150 \mathrm{~m})$ of high and moderate biomass according to CTD calibrated fluorescence profiles. Stations (Stns) E-3, E-4W (west), E-4E 


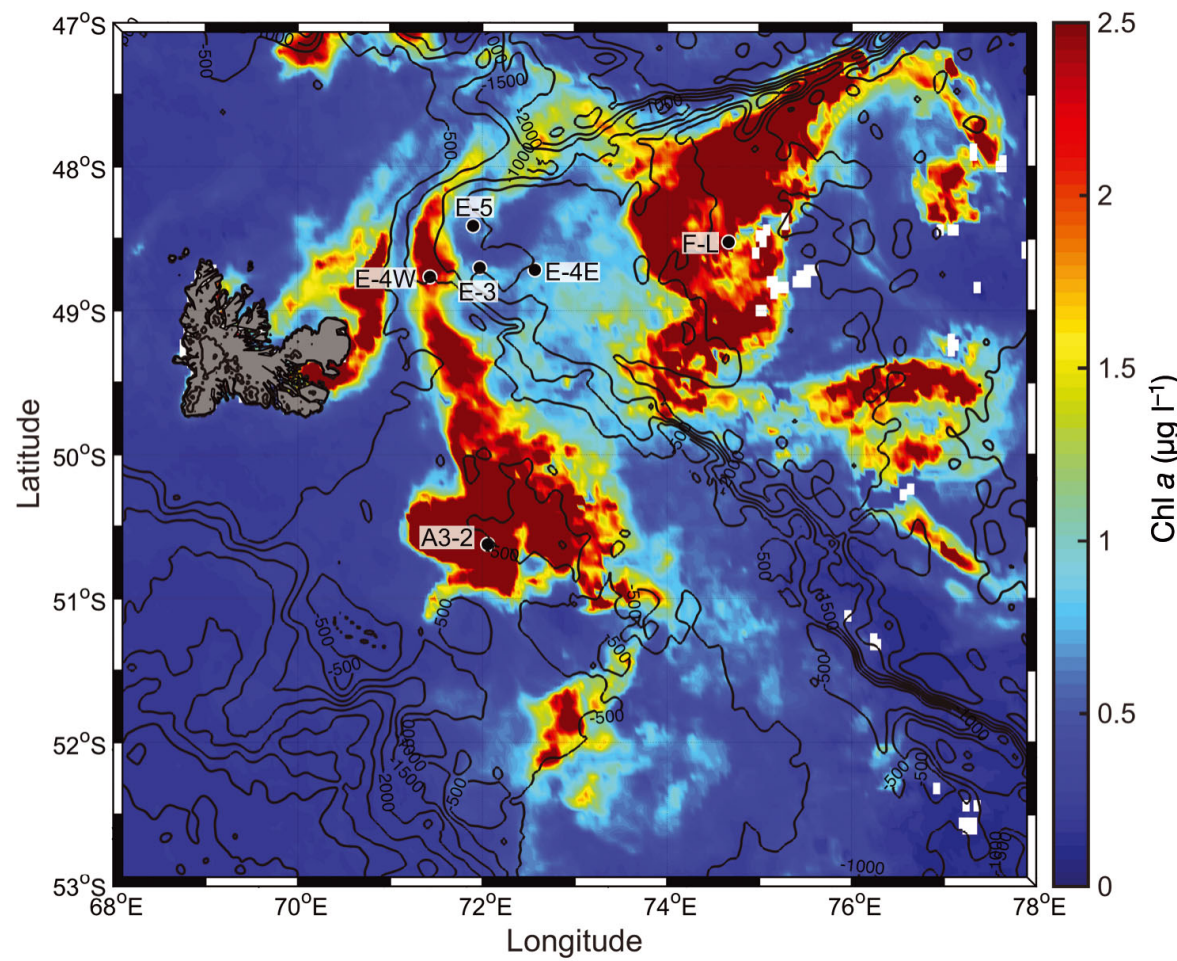

Fig. 2. Sampling stations over the Kerguelen Plateau on a MODIS satellite image of surface chl a concentration on 11 November 2011. Location of each station and sampling date (dd/mm/yyyy): E-3: $\quad 71.97^{\circ} \mathrm{E}, \quad 48.704^{\circ} \mathrm{S} \quad(4 / 11 / 2011)$; F-L: $74.668^{\circ} \mathrm{E}, \quad 48.523^{\circ} \mathrm{S} \quad(6 / 11 / 2011)$; $\mathrm{E}-4 \mathrm{~W}: 7^{2} .43^{\circ} \mathrm{E}, 48.766^{\circ} \mathrm{S}(11 / 11 / 2011)$; E-4E: $72.567^{\circ} \mathrm{E}, 48.717^{\circ} \mathrm{S}(13 / 11 / 2011)$; A3-2: $72.055^{\circ} \mathrm{E}, 50.624^{\circ} \mathrm{S}(16 / 11 / 2011)$; E-5: $71.9^{\circ} \mathrm{E}, 48.412(19 / 11 / 2011)$

(east), and E-5 formed a time series within a moderate biomass, eddy-like, bathymetrically-trapped recirculation feature in deep waters east of the Kerguelen Islands. Stns F-L and A3-2 were respectively in a region of elevated biomass near the Polar front and at the Kerguelen on-plateau bloom reference station of KEOPS1 (A3). Seawater was sampled using 121 Niskin bottles mounted on a CTD rosette frame. At each station the whole content of 2 Niskin bottles was transferred into a clean 301 carboy to avoid any undersampling of particulate organic matter from the Niskins. Sampling was repeated at 2 different depths at each site ( 2 carboys per station). The carboys were stored in darkness for $1 \mathrm{~d}$ to initiate phytoplankton senescence.

\section{Roller tank experiments}

Carboy contents were poured into $10 \mathrm{l}$ transparent cylindrical tanks cleaned previously with $2 \%$ alkaline detergent (Decon) and washed 3 times with extra sampled seawater. At each station, 4 cylindrical tanks (2 duplicates by depth, except at E-4E where deeper layers were not sampled) were placed on a rolling table at a constant speed of $0.66 \mathrm{rpm}$ and kept in darkness during the entire duration of the incubation. All experiments were conducted at a temperature of $\sim 10^{\circ} \mathrm{C}$. To obtain sufficient millimeter sized aggregates to perform the chemical measurements on individual aggregates, incubations lasted from 1 to $4 \mathrm{~d}$.
Measurements were conducted on 3 aggregates per tank (12 aggregates per experiment). When possible, aggregate selection was made in order to capture large variations of size, shape (e.g. spherical to elongated), and compactness (e.g. compact to loose). In each experiment, 6 aggregates were used for chemical measurements and 6 preserved in Lugol's solution for post-cruise microscopic observations in the laboratory.

\section{Measurement of aggregate morphology and structure}

At the end of the incubation, the tanks were removed from the rolling table and carefully rotated $90^{\circ}$ to allow the aggregates to settle to the bottom. The maximum length of the 3 aggregates selected per tank was measured optically. Each aggregate was photographed through the bottom of the tank with a high-resolution Canon Powershot G12 camera (1 pixel $\approx 20 \mu \mathrm{m}$ ). The images were thresholded to create binary images and processed using the US National Institutes of Health free software, Image $\mathrm{J}$ (Abràmoff et al. 2004). The minimum length was taken to be the minimum axis of the ellipse fitted to the shape by the software. The aspect ratio (AR) was calculated from the ratio between smallest and largest axes of the fitted ellipse. The commonly used Corey shape factor (CSF) (Corey 1949, McNown \& Malaika 1950) representing particle flatness (low val- 
ues of CSF corresponding to flat particles) was also used as a shape descriptor. The equivalent spherical diameter (ESD) and volume of aggregates were calculated from the projected area, assuming a sphere.

We characterized the fractal structure of our aggregates by determining their 1-, 2- and 3-dimensional fractal numbers $D_{\mathrm{F} 1}, D_{\mathrm{F} 2}$ and $D_{\mathrm{F} 3}$, respectively. The number of individual particles $(N)$ composing a fractal aggregate increases non-linearly with its size and can be described by the power relationship (Logan \& Wilkinson 1990):

$$
N \sim 1^{D \mathrm{Fn}}
$$

where $D_{\mathrm{F} n}$ is the fractal dimension determined for the object in $n$ dimensions, and $l$ is the maximum length of the aggregate. Since phytoplankton aggregates and their constitutive particles have finite sizes, they are not strictly self-similar at all scales and their fractal dimensions are approximations to real fractal dimensions obtained only for infinite size objects. The fractal dimension describes intuitively how much the individual particles fill the available space when they aggregate (e.g. Logan \& Wilkinson 1990, Kilps et al. 1994, Jackson 1998, Burd \& Jackson 2009) and is an indicator of particle compactness.

The maxima of $D_{\mathrm{F} 1}=1, D_{\mathrm{F} 2}=2$ and $D_{\mathrm{F} 3}=3$ are reached for Euclidean objects. For instance, $D_{\mathrm{F} 3}=3$ describes a solid compact sphere having no porosity where all individual particles filled the total volume available when they assembled. Unlike Euclidean objects, aggregates formed in marine systems, such as marine snow, have lower fractal dimension than their maximum values (Logan \& Wilkinson 1990). It implies that the number of particles filling the space during aggregation increases at a lower rate than aggregate maximum length does. It results in the important property that marine snow has a porosity increasing with size (Logan \& Wilkinson 1990), consequently reducing its excess density.

Following Kilps et al. (1994), the 1- and 2-dimensional fractal numbers $\left(D_{\mathrm{F} 1}\right.$ and $\left.D_{\mathrm{F} 2}\right)$, were calculated from the slopes of log-log relationships of perimeter and area respectively, against the Feret's diameter representing the largest dimension (e.g. Engel et al. 2009). The 3-dimensional fractal number $\left(D_{\mathrm{F} 3}\right)$ can be calculated from the slope of a log-log relationship between solid content ( 1 - Porosity) and the largest diameter $l$, according to the formula proposed by Logan \& Wilkinson (1990):

$$
(1-P)=a \times 1^{D_{\mathrm{F} 3}-3}
$$

where $a$ is an empirical constant. Due to large uncertainties on solid content estimates, especially for TEP (see 'Chemical measurements' below), $D_{\mathrm{F} 3}$ values for the experimental aggregates could not be reliably obtained, and only $D_{\mathrm{F} 1}$ and $D_{\mathrm{F} 2}$ results, based on image analysis, are presented. To avoid any bias due to small scale heterogeneity between images, no conversion from pixels to size unit was made for $D_{\mathrm{F} 1}$ and $D_{\mathrm{F} 2}$ determination.

\section{Sinking velocity measurements}

A non-destructive method was required to measure the sinking velocity and still be able to conduct other analyses on single aggregates. A method based on video recording the rotating tanks (Ploug et al. 2010) was not applicable onboard because of the ship motion altering the trajectories of particles. Instead, all the settling rates were measured directly inside the tanks using a $13.5 \mathrm{~mm}$ diameter and $23 \mathrm{~cm}$ long pipette acting as a static column. Right after the morphological measurements, the pipette was inserted and filled with water sampled at the surface of the tank. An aggregate was then selected at the bottom and gently sucked up into the pipette to the height of the water in the tank. The aggregate then sank freely in the column for several centimeters, and the average sinking velocity was measured over a distance of $7 \mathrm{~cm}$ at its apparent terminal velocity. Working directly inside the tanks avoided any transfer of the aggregates likely to alter their structure. Only 1 measurement was done on each aggregate due to their extremely fragile nature and the high probability of breaking, matter loss or structural alteration occuring during repeated manipulations, which would have flawed the study.

The length and diameter of the pipette limited the influence of turbulence induced by ship motion, which otherwise could be responsible for a bias in sinking velocity measurements. Nevertheless, our column dimensions presented possible issues worthy of evaluation. Specifically, the method would be in error if (1) wall effects affected aggregate sinking velocity without a clear correlation with size, thus recluding a reliable correction, or (2) aggregates did not reach their terminal velocity during settling. We determined the wall factor ( $f_{i}$ Chhabra 1995), defined as the ratio between the assumed terminal velocity of a particle in our pipette to that in a $50 \mathrm{~cm}$ high and $20 \mathrm{~cm}$ wide cylinder considered as an unbounded medium. Following the protocol of Ploug et al. (2010), we made agar spheres of 0.4 to $1 \mathrm{~cm}$, used as model particles and covering most of the size range of our roller tank aggregates. The deviation to the Stokes' 
law expectations for our pipette and large cylinder was assessed by the use of $1 \mathrm{~mm}$ polystyrene beads (Duke Scientific, 4400A, $1004 \pm 20 \mu \mathrm{m}, \rho=1.05 \mathrm{~g} \mathrm{~cm}^{-3}$ ) sinking in filtered seawater (temperature $T=21^{\circ} \mathrm{C}$; salinity $\mathrm{S}=34.57$; dynamic viscosity $\mu=105 \times 10^{-5} \mathrm{~kg}$ $\mathrm{m}^{-1} \mathrm{~s}^{-1} ; \rho_{\mathrm{sw}}=1.0243 \mathrm{~g} \mathrm{~cm}^{-3}$ ). Over more than 70 measurements, polystyrene beads sank at very similar velocities in the large cylinder and pipette (mean $\pm \mathrm{SD}$ : $941 \pm 37$ and $911 \pm 51 \mathrm{~m} \mathrm{~d}^{-1}$, respectively) suggesting that the pipette induced a negligible wall effect and permitted the particles to sink close to their terminal velocity. At this water temperature and salinity, theoretical expectations from Stokes' law for the minimum and maximum bead sizes possibly encountered in our batch (984 and $1024 \mu \mathrm{m}$ ) led to sinking velocities of 862 and $933 \mathrm{~m} \mathrm{~d}^{-1}$, respectively, very close to our experimental values. For larger particles, modeled by agar spheres, the pipette induced a wall effect well correlated with size: $f=-0.084 \times \mathrm{ESD}(\mathrm{mm})+1.1(\mathrm{n}=$ $\left.28, r^{2}=0.98, p<0.005\right)$. A correction based on this correlation was applied on our aggregate sinking velocities. In addition, as a precaution, all sinking velocity measurements of aggregates $>8 \mathrm{~mm}$ ESD (where the largest correction applies) were excluded from the study. The correction augmented the measured values by $50 \pm 30 \%$ on average. It corresponded to an increase of $30 \pm 29 \mathrm{~m} \mathrm{~d}^{-1}$ and represented a limited alteration of the raw data, which extended over 2 orders of magnitude.

\section{Chemical measurements}

Each individual aggregate was collected in $10 \mathrm{ml}$ of tank water and directly processed or stored $<1 \mathrm{~d}$ at $2^{\circ} \mathrm{C}$ in $15 \mathrm{ml}$ Falcon tubes. These $10 \mathrm{ml}$ were homogenized and then divided into thirds for particulate organic carbon (POC), BSi and TEP measurements. Since each aggregate was sampled along with $10 \mathrm{ml}$ of tank water, these 3 components were also measured in the tank water, and that amount was subtracted to yield the amount contained only within the aggregate.

BSi was measured following the alkaline extraction and colorimetric analysis procedure of Ragueneau et al. (2005). Subsamples were filtered onto $25 \mathrm{~mm}$ polycarbonate $0.4 \mu \mathrm{m}$ pore filters, dried at $60^{\circ} \mathrm{C}$ in Eppendorf vials, sealed and stored at room temperature until analysis.

TEP were measured using a spectrophotometric method in accordance with Passow \& Alldredge (1995). Subsamples were filtered onto $25 \mathrm{~mm}$ polycarbonate $0.4 \mu \mathrm{m}$ pore filters and stained with $500 \mu \mathrm{l}$ of a $0.02 \%$ aquaeous solution of Alcian blue in $0.06 \%$ acetic acid. The filters were stored in Eppendorf vials and immediately frozen at $-20^{\circ} \mathrm{C}$. Prior to analysis, all samples were soaked onboard for $2 \mathrm{~h}$ in $6 \mathrm{ml}$ of $80 \% \mathrm{H}_{2} \mathrm{SO}_{4}$ to redissolve the stain. The absorbance of the solution was measured at $787 \mathrm{~nm}$ with a spectrophotometer to quantify the TEP. The calibration curve relating the absorbance to the amount of TEP was established in the laboratory after the voyage with the remaining Alcian blue stock, using a protocol modified from Passow \& Alldredge (1995).

TEP determination is semi-quantitative, as the chemical composition varies and is mostly unknown (Passow 2012). The accuracy of measured TEP content depends on the ability of the batch of xanthan gum (XG) to behave like TEP during the calibration, and on variations in Alcian blue staining properties between measurements done onboard and calibration done in the laboratory. The use of different batches of XG or Alcian blue leads therefore to a high variability and renders difficult quantitative comparisons between distinct works. Alcian blue is a hydrophilic cationic dye that complexes with anionic carboxyl or halfester-sulfate groups of acidic polysaccharides, and the selectivity of the stain depends on the $\mathrm{pH}$ and salt content of the dye solution (Passow $\&$ Alldredge 1995). These properties are of course altered during the staining process, further influencing the possibility of variable or non-specific staining. In addition, the ratio of non-TEP material potentially stainable by Alcian blue to strict TEP may be higher in small or low TEP content samples.

POC content was determined by CHN elemental analysis using a Thermo Finnigan EA1112 Flash Elemental Analyser and acetanilide standards. Each subsample was filtered through a Sartorius T293 $13 \mathrm{~mm}$ quartz filter (polycarbonate filter holder) with a nominal pore size of $0.8 \mu \mathrm{m}$ (precombusted at $450^{\circ} \mathrm{C}$ for $4 \mathrm{~h}$ in clean foil to remove carbon contamination). The filters were blown dry using filtered air and then transferred to a clean, gravity circulation oven and dried at $50^{\circ} \mathrm{C}$ for more than $48 \mathrm{~h}$. On completion of the sample set, the dry filters were loaded into silver $5 \times$ $9 \mathrm{~mm}$ capsules (Sercon SC0037), acidified with $40 \mu \mathrm{l}$ of $2 \mathrm{~N} \mathrm{HCl}$, dried for at least $48 \mathrm{~h}$ at $60^{\circ} \mathrm{C}$, encapsulated and then stored over silica gel. Aggregate content in POM was estimated from POC values assuming a POM:POC mass ratio of 1.87 (Anderson 1995).

Particulate inorganic carbon (PIC), a potentially important ballast mineral, was not measured because analyses of particles collected by large volume filtration revealed PIC to be very low, at levels that would have been below detection in the individual aggregates. 


\section{Microscope observations}

Each aggregate reserved for microscopic observation was collected in Eppendorf vials in $1.5 \mathrm{ml}$ of tank water and preserved with 1 drop of Lugol's solution. In the laboratory, the samples were resuspended in $3 \mathrm{ml}$ of artificial seawater and transfered to a microscopy chamber for observation with a Zeiss Axio Observer A1 high-magnification inverted microscope. An average of 60 pictures per sample was taken at several magnifications $(\times 160,320$ and 640$)$ to cover the entire observable field. Pictures were used to identify numbers, sizes and genera (or species when possible) of phytoplankton and other organisms. An average cell diameter (or maximum length for non-circular species), excluding the length of setae (spines) when present, was calculated by sizing a few to $>10$ specimens of the organism, depending on its abundance in the aggregate. In order to investigate the potential influence of various phytoplankton morphological types on the sinking velocity, proportions of chain diatoms without setae (e.g. Fragilariopsis spp. and Eucampia antarctica) and small setaeforming diatoms (e.g. Chaetoceros spp.) were calculated. For simplicity, we refer to chain diatoms without setae as 'type 1' and to small setae-forming diatoms as 'type 2 ' in the rest of the text.

\section{Multivariate analyses}

Multiple regression analyses were conducted to quantify the relative contribution of size, as opposed to the other factors measured, in the prediction of sinking velocity variations. All analyses were performed using the statistical computing language and environment R. Since chemical composition and phytoplankton type contents were analysed on 2 different sets of aggregates, 2 distinct multiple regressions were carried out. The first model, fitted to the chemical composition data (fit 1), regressed sinking velocity against projected area, volume, ESD, Corey shape factor (CSF), aspect ratio (AR), and average mass fractions of $\mathrm{BSi}, \mathrm{POM}$ and TEP in aggregate solid contents; the second model, fitted to the phytoplankton data (fit 2), regressed sinking velocity against projected area, volume, ESD, CSF, AR, and average type 1 and type 2 phytoplankton cell fractions in aggregates.

Linear regressions were applied, and the relative contribution of the parameters to the correlation was assessed by estimating the variation on the correlation coefficient $\left(\mathrm{r}^{2}\right)$ induced by removals of terms from the fit. To limit biases due to collinearity, parameters indicating the same aggregate property (size, shape, chemical or phytoplankton composition), were grouped and removed together. To identify aggregate properties playing the most important controls on the sinking velocity, ANOVAs were performed; the 2 models containing all terms (fits 1 and 2) were compared to the reduced models by a reduced sums of square $F$-test; with $\mathrm{p}<0.05$ used as indicator of a significant change.

\section{RESULTS}

All morphological properties and compositions of the aggregates are reported in Table 1. Comparisons of sinking velocity and several aggregate properties from morphology (AR and CSF) to composition (BSi, TEP, POM and plankton content) were conducted to assess the possible effect of sampling depth on aggregate properties. No significant statistical difference was found between aggregates made from water sampled in surface layers and deeper layers $(1>p>0.45)$ for a selected sample of the measured properties (sinking velocity, shape, chemical composition, phytoplankton content), and thus no distinction is made between these 2 aggregate groups in the rest of the study.

\section{Sinking velocity}

Sinking velocity data, corrected for wall effects, ranged from 13 to $260 \mathrm{~m} \mathrm{~d}^{-1}$ (1 aggregate sank at $569 \mathrm{~m} \mathrm{~d}^{-1}$ but this extreme value was excluded, along with all sinking velocity measurements for aggregates $>8 \mathrm{~mm}$ ESD, as explained in 'Materials and methods: Sinking velocity measurements'). In Fig. 3, data from each site are compared to expectations from the Stokes' law and general sinking velocity models for porous fractal particles. For these expectations, theoretical excess densities were calculated assuming 3 major solid components in fixed volume fractions (TEP:0.3, BSi:0.2, POM:0.5). These proportions are based on measured values of BSi and POC presenting the best scaling with size (see Fig. 6) and using a TEP:POC mass ratio of 0.7 (Alldredge et al. 1998, Martin et al. 2011). The theoretical porosity was scaled with size according to a fractal relationship (Eq. 8).

TEP, BSi, POM and seawater densities were fixed at $800,2000,1060$ and $1026 \mathrm{~g} \mathrm{~cm}^{-3}$ respectively, according to documented values (Klaas \& Archer 2002, 
Table 1. Composition and morphological parameters of aggregates (Agg.) made in roller tank experiments conducted at 6 stations (Stn; see Fig. 2 for locations and sampling dates). Incub.: days of incubation in each tank; l: length (max/min) of Agg.; ESD: equivalent spherical diameter; SV: sinking velocity; BSi: biogenic silica; POC: particulate organic carbon; TEP: transparent exopolymeric particles; XG: xanthan gum (table continued on next page)

\begin{tabular}{|c|c|c|c|c|c|c|c|c|c|c|c|c|c|c|}
\hline Agg. & Stn & $\begin{array}{c}\text { Depth } \\
\text { (m) }\end{array}$ & $\begin{array}{c}\text { Tank } \\
\#\end{array}$ & $\begin{array}{c}\text { Incub. } \\
\text { (d) }\end{array}$ & $\begin{array}{c}l_{\max } \\
(\mathrm{mm})\end{array}$ & $\begin{array}{c}l_{\min } \\
(\mathrm{mm})\end{array}$ & $\begin{array}{l}\text { ESD } \\
(\mathrm{mm})\end{array}$ & $\begin{array}{c}\mathrm{SV} \\
\left(\mathrm{m} \mathrm{d}^{-1}\right)\end{array}$ & $\begin{array}{c}\text { BSi } \\
(\mu \mathrm{mol})\end{array}$ & $\begin{array}{c}\text { POC } \\
(\mu \mathrm{mol})\end{array}$ & $\begin{array}{c}\text { TEP } \\
\text { ( } \mu \text { g XG } \\
\text { equi- } \\
\text { valent) }\end{array}$ & $\begin{array}{c}\text { Mean } \\
\text { cell } \\
\text { diameter } \\
(\mu \mathrm{m})\end{array}$ & $\begin{array}{c}\text { \% chain } \\
\text { diatom } \\
\text { without } \\
\text { setae }\end{array}$ & $\begin{array}{l}\text { \% small } \\
\text { setae- } \\
\text { forming } \\
\text { diatom }\end{array}$ \\
\hline 1 & E-3 & 30 & 1 & 3 & 12 & 9 & 9.2 & 569 & 3.6 & 10.6 & 488 & - & - & - \\
\hline 2 & I & 1 & 1 & 1 & 3 & 2 & 2.7 & 143 & 0.1 & 2.7 & 210 & - & - & - \\
\hline 3 & I & 1 & 1 & 1 & 4 & 2 & 2.6 & 149 & 0.1 & 0.9 & 199 & - & - & - \\
\hline 4 & I & 1 & 1 & 1 & 3 & 2 & 1.9 & 98 & 0.2 & 0.6 & 232 & - & - & - \\
\hline 5 & I & 1 & 1 & 1 & 5 & 1 & 2.2 & 114 & 0.1 & 1.0 & 199 & - & - & - \\
\hline 6 & I & 1 & 2 & 3.3 & 4 & 2 & 3.5 & 161 & - & - & - & 52 & 43 & 12 \\
\hline 7 & I & I & 2 & I & 6 & 3 & 4.3 & 220 & - & - & - & 54 & 65 & 5 \\
\hline 8 & I & 1 & 2 & 1 & 3 & 2 & 2.1 & 105 & - & - & - & 54 & 69 & 3 \\
\hline 9 & I & 150 & 3 & 3.3 & 6 & 4 & 4.4 & 258 & 0.4 & 1.1 & 283 & - & - & - \\
\hline 10 & I & 1 & 3 & 1 & 10 & 3 & 4.6 & 168 & 0.9 & 4.5 & 150 & - & - & - \\
\hline 11 & I & 1 & 4 & 3.5 & 20 & 5 & 2.2 & 113 & - & - & - & 58 & 65 & 4 \\
\hline 12 & I & I & 4 & I & 10 & 1 & 4.6 & 109 & - & - & - & 69 & 55 & 0 \\
\hline 13 & F-L & 20 & 1 & 1 & 7 & 4 & 5.2 & 135 & 0.6 & 1.6 & 272 & - & - & - \\
\hline 14 & I & 1 & 1 & 1 & 6 & 3 & 4.1 & 89 & 0.4 & 3.9 & 272 & - & - & - \\
\hline 15 & I & 1 & 1 & 1 & 10 & 6 & 5.6 & 127 & 1.9 & 4.7 & 439 & - & - & - \\
\hline 16 & I & 1 & 2 & 1 & 10 & 7 & 7.0 & 158 & - & - & - & 41 & 30 & 4 \\
\hline 17 & I & 1 & 2 & I & 4 & 1 & 1.6 & 58 & - & - & - & 48 & 23 & 12 \\
\hline 18 & I & 1 & 2 & 1 & 8 & 4 & 4.9 & 145 & - & - & - & 29 & 25 & 13 \\
\hline 19 & I & 65 & 3 & 1 & 7 & 5 & 5.7 & 254 & 1.4 & 4.4 & 286 & - & - & - \\
\hline 20 & I & 1 & 3 & I & 5 & 3 & 3.7 & 96 & 0.2 & 1.1 & 209 & - & - & - \\
\hline 21 & I & 1 & 3 & 1 & 3 & 1 & 1.3 & 87 & 0.1 & 0.4 & 242 & - & - & - \\
\hline 22 & 1 & 1 & 4 & 1 & 12 & 6 & 7.4 & 203 & - & - & - & 32 & 13 & 32 \\
\hline 23 & I & 1 & 4 & I & 7 & 4 & 4.8 & 167 & - & - & - & 35 & 7 & 40 \\
\hline 24 & I & 1 & 4 & 1 & 4 & 2 & 2.1 & 79 & - & - & - & 41 & 5 & 36 \\
\hline 25 & E-4W & 30 & 1 & 1.2 & 15 & 7 & 8.7 & 46 & 0.7 & 0.3 & 377 & - & - & - \\
\hline 26 & I & I & 1 & I & 15 & 12 & 10.3 & 66 & 1.0 & 0.8 & 377 & - & - & - \\
\hline 27 & I & I & 1 & I & 15 & 12 & 12.3 & 172 & 1.0 & 1.7 & 333 & - & - & - \\
\hline 28 & I & i & 2 & 1.3 & 10 & 7 & 7.0 & 17 & - & - & - & 34 & 14 & 56 \\
\hline 29 & I & I & 2 & I & 10 & 5 & 5.6 & 23 & - & - & - & 37 & 11 & 56 \\
\hline 30 & I & I & 2 & I & 8 & 6 & 5.6 & 23 & - & - & - & 36 & 18 & 37 \\
\hline 31 & I & 80 & 3 & 1.3 & 8 & 4 & 4.6 & 23 & 0.5 & 0.5 & 109 & - & - & - \\
\hline 32 & I & 1 & 3 & 1 & 10 & 7 & 6.9 & 30 & 0.4 & 13.0 & 298 & - & - & - \\
\hline 33 & I & 1 & 3 & I & 10 & 7 & 7.1 & 13 & 1.0 & 1.8 & 287 & - & - & - \\
\hline 34 & I & 1 & 4 & 1.4 & 10 & 6 & 6.6 & 17 & - & - & - & 25 & 2 & 68 \\
\hline 35 & I & 1 & 4 & 1 & 13 & 8 & 9.1 & 60 & - & - & - & 38 & 10 & 44 \\
\hline 36 & I & I & 4 & 1 & 10 & 8 & 7.3 & 24 & - & - & - & 29 & 15 & 47 \\
\hline 37 & $E-4 E$ & 30 & 1 & 1.1 & 11 & 6 & 7.8 & 240 & 1.1 & 2.0 & 166 & - & - & - \\
\hline 38 & I & 1 & 1 & 1 & 12 & 6 & 7.4 & 217 & 1.2 & 2.1 & 300 & - & - & - \\
\hline 39 & I & I & 1 & I & 5 & 3 & 4.1 & 145 & 0.5 & 2.4 & 133 & - & - & - \\
\hline 40 & I & 1 & 2 & 1.2 & 6 & 4 & 4.6 & 184 & - & - & - & 44 & 26 & 56 \\
\hline 41 & I & I & 2 & I & 7 & 5 & 5.5 & 173 & - & - & - & 58 & 40 & 17 \\
\hline 42 & I & 1 & 2 & I & 7 & 5 & 5.2 & 198 & - & - & - & 56 & 33 & 30 \\
\hline 43 & A3-2 & 30 & 1 & 1.2 & 7 & 5 & 5.7 & 74 & 0.5 & 2.1 & 60 & - & - & - \\
\hline 44 & I & I & 1 & I & 7 & 5 & 4.8 & 64 & 0.4 & 2.6 & 160 & - & - & - \\
\hline 45 & I & i & 1 & i & 8 & 3 & 4.2 & 20 & 0.2 & 1.2 & 160 & - & - & - \\
\hline 46 & I & i & 2 & 1.3 & 7 & 5 & 5.3 & 60 & - & - & - & 22 & 4 & 77 \\
\hline 47 & I & 1 & 2 & I & 6 & 4 & 4.0 & 46 & - & - & - & 22 & 8 & 48 \\
\hline 48 & I & I & 2 & I & 7 & 4 & 4.6 & 60 & - & - & - & 17 & 0 & 67 \\
\hline 49 & I & 80 & 3 & 1.3 & 7 & 6 & 5.4 & 73 & 0.6 & 2.8 & 156 & - & - & - \\
\hline 50 & I & I & 3 & I & 7 & 3 & 3.6 & 49 & 0.6 & 1.8 & 289 & - & - & - \\
\hline 51 & I & 1 & 3 & 1 & 7 & 6 & 5.7 & 52 & 0.3 & 1.2 & 78 & - & - & - \\
\hline 52 & I & 1 & 4 & 1.4 & 8 & 7 & 6.7 & 59 & - & - & - & 14 & 2 & 81 \\
\hline 53 & I & I & 4 & I & 7 & 5 & 4.6 & 52 & - & - & - & 26 & 11 & 53 \\
\hline 54 & 1 & 1 & 4 & I & 7 & 6 & 5.8 & 37 & - & - & - & 17 & 2 & 85 \\
\hline
\end{tabular}


Table 1 (continued)

\begin{tabular}{|c|c|c|c|c|c|c|c|c|c|c|c|c|c|c|}
\hline Agg. & Stn & $\begin{array}{l}\text { Depth } \\
\text { (m) }\end{array}$ & $\begin{array}{c}\text { Tank } \\
\#\end{array}$ & $\begin{array}{l}\text { Incub. } \\
\text { (d) }\end{array}$ & $\begin{array}{c}l_{\max } \\
(\mathrm{mm})\end{array}$ & $\begin{array}{c}l_{\min } \\
(\mathrm{mm})\end{array}$ & $\begin{array}{l}\text { ESD } \\
(\mathrm{mm})\end{array}$ & $\begin{array}{c}\mathrm{SV} \\
\left(\mathrm{m} \mathrm{d}^{-1}\right)\end{array}$ & $\begin{array}{c}\mathrm{BSi} \\
(\mu \mathrm{mol})\end{array}$ & $\begin{array}{c}\text { POC } \\
(\mu \mathrm{mol})\end{array}$ & $\begin{array}{c}\text { TEP } \\
\text { ( } \mu \text { g XG } \\
\text { equi- } \\
\text { valent) }\end{array}$ & $\begin{array}{c}\text { Mean } \\
\text { cell } \\
\text { diameter } \\
(\mu \mathrm{m})\end{array}$ & $\begin{array}{c}\text { \% chain } \\
\text { diatom } \\
\text { without } \\
\text { setae }\end{array}$ & $\begin{array}{l}\text { \% small } \\
\text { setae- } \\
\text { forming } \\
\text { diatom }\end{array}$ \\
\hline 55 & E-5 & 30 & 1 & 2.7 & 8 & 6 & 5.7 & 80 & 0.7 & 4.0 & 335 & - & - & - \\
\hline 56 & 1 & I & 1 & I & 7 & 6 & 5.7 & 67 & 0.6 & 2.5 & 290 & - & - & - \\
\hline 57 & I & I & 1 & I & 5 & 3 & 3.6 & 46 & 0.2 & 4.2 & 68 & - & - & - \\
\hline 58 & I & I & 2 & 2.7 & 9 & 6 & 6.4 & 62 & - & - & - & 58 & 23 & 21 \\
\hline 59 & I & I & 2 & 1 & 8 & 6 & 5.5 & 40 & - & - & - & 76 & 9 & 23 \\
\hline 60 & I & 1 & 2 & I & 8 & 5 & 5.1 & 43 & - & - & - & 59 & 25 & 27 \\
\hline 61 & I & 80 & 3 & 2.7 & 8 & 6 & 6.6 & 91 & 1.3 & 2.7 & 405 & - & - & - \\
\hline 62 & i & I & 3 & I & 5 & 3 & 3.7 & 72 & 0.3 & 3.1 & 138 & - & - & - \\
\hline 63 & 1 & i & 3 & 1 & 6 & 4 & 3.1 & 50 & 0.3 & 2.5 & 138 & - & - & - \\
\hline 64 & I & I & 4 & 2.8 & 5 & 3 & 3.8 & 75 & - & - & - & 92 & 40 & 14 \\
\hline 65 & 1 & I & 4 & I & 5 & 3 & 3.7 & 74 & - & - & - & 89 & 52 & 7 \\
\hline 66 & 1 & I & 4 & I & 7 & 3 & 4.6 & 60 & - & - & - & 80 & 25 & 25 \\
\hline
\end{tabular}

Azetsu-Scott \& Passow 2004). All calculations assumed a dynamic viscosity of $0.00135 \mathrm{~kg} \mathrm{~m}^{-1} \mathrm{~s}^{-1}$ chosen according to the conditions existing in the tanks $\left(T=\sim 10^{\circ} \mathrm{C}\right.$ and $\left.\mathrm{S}=34\right)$.

Using the drag coefficient calculated at an observed data point from its sinking velocity and size (called here 'specific conditions'), the apparent Reynolds number for this particle was determined by solving numerically the empirical relationship from White (1974), valid for a large range of $\mathrm{Re}$ $\left(0.5<\operatorname{Re}<2 \times 10^{5}\right)$ :

$$
C_{\mathrm{D}}=\frac{24}{\mathrm{Re}}+\frac{6}{1+\mathrm{Re}^{0.5}}+0.4
$$

The general model curves for other particle sizes were then calculated from this chosen observed value and the linear proportionality between Re and size, i.e. as embedded in the definition of the Reynolds number (Eq. 2).

The variation in the relationship between sinking velocity and size was explored for different fractal

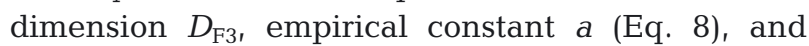
specific conditions determining distinct initial drag coefficients. Fig. 3A shows that the steepest slope is obtained for the solid spheres $\left(D_{\mathrm{F} 3}=3\right)$ of the Stokes' law model assuming a constant particle excess density. The different general sinking velocity models display decreasing slopes for $D_{\mathrm{F} 3}$ values from 1.8 to 1.2 , leading to a possible decrease of the sinking velocity with increasing size for low fractal numbers. This result suggests that for high fractal dimensions (compact aggregates), the size exerts a stronger control on the sinking velocity than for lower fractal dimensions (loose aggregates), and highlights the possible dominance of structure over size. For distinct specific conditions (distinct initial drag coefficients; 1 and 2 on Fig. 3A), the solutions converge when size increases, consistent with a decreasing influence of the drag coefficient in comparison to size.

Fig. 3B illustrates the sensitivity of the model curves to the empirical constant $a$, for 2 distinct fractal dimensions. The large variations of the curve slopes for a varying over several orders of magnitude (0.001 to 100), and particularly for small values of $a$, suggests that an accurate characterization of aggregate structure requires the fractal dimension to be used in combination with the constant $a$.

Fig. 3C shows tight correlations between sinking velocity and ESD when considering each site separately, suggesting the existence of site-specific parameters which alter the size-sinking velocity relationship. The general sinking velocity models are compared to data from each experiment with specific conditions of sinking velocity and ESD of each model corresponding to an average of all data of the experiment considered, assumed to reflect its drag characteristics. The best model fits to the data, agreeing with realistic values expected for marine snow, were obtained by decreasing $D_{\mathrm{F} 3}$ from 1.8 in experiments with the highest sinking velocities, to 1.2 in experiments with the lowest sinking velocities. Data slopes were reproduced by the model curves with variable accuracy, suggesting that fractal structure may have varied from one experiment to another. 

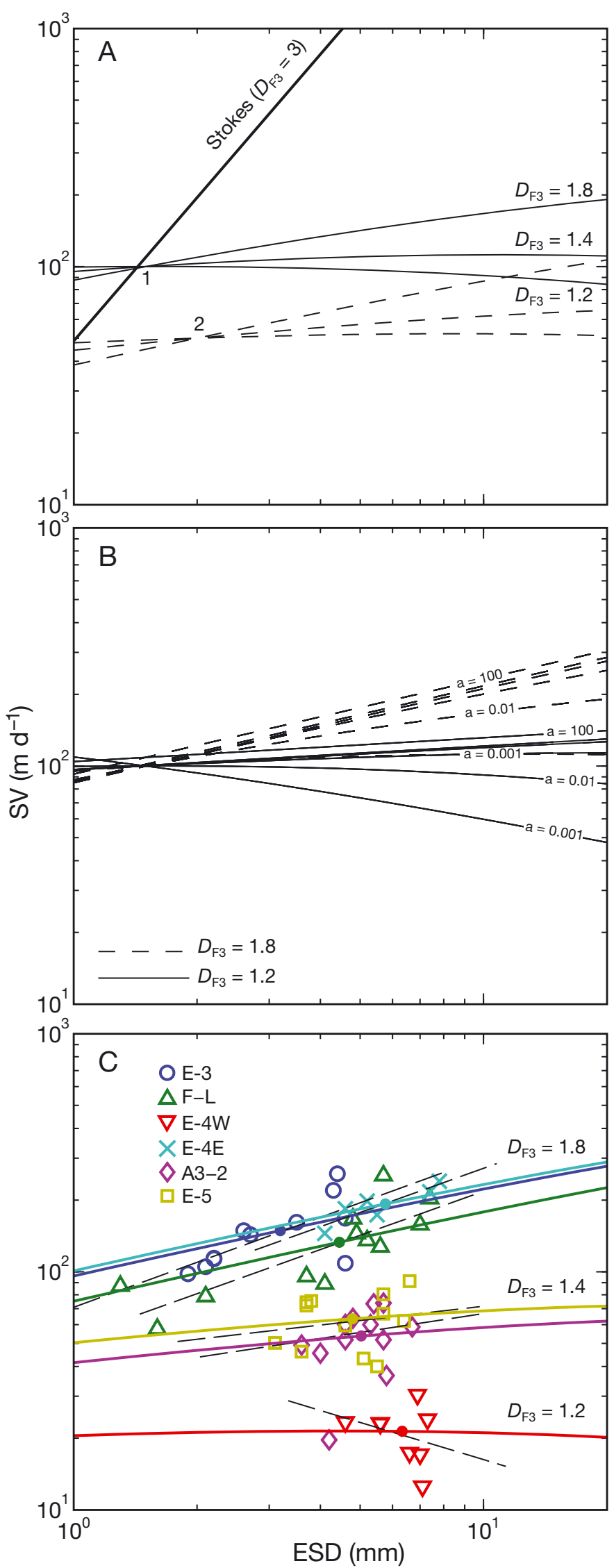

\section{Morphology and fractal numbers $D_{\mathrm{F} 1}$ and $D_{\mathrm{F} 2}$}

Aggregates formed in roller tanks had similar shapes to aggregates collected in polyacrylamide gel-filled sediment traps at similar times and locations (Fig. 4). Maximum lengths ranged from 3 to $20 \mathrm{~mm}$, and projected areas from 1.3 to $118 \mathrm{~mm}^{2}$, leading to ESD of 1.3 to $12.3 \mathrm{~mm}$ (Table 1) and volumes of 1.1 to $965 \mu \mathrm{l}$. Their aspect ratios extended from 1.03 to 4.15 , except one very long 'cometshaped' aggregate with an extreme value of 13. The Corey shape factors ranged from 0.26 to 0.95 . Overall, aggregates produced in roller tank experiments were bigger than natural aggregates (ESD: $\sim 0.1$ to $1.4 \mathrm{~mm}$ ). This is the result of our choice to maintain incubations over a duration long enough to provide sufficient material for the chemical measurements.

Fractal numbers $D_{\mathrm{F} 1}$ and $D_{\mathrm{F} 2}$ of aggregates produced in roller tanks were $1.49 \pm 0.16$ and $1.82 \pm 0.18$ respectively (Fig. 5), and also close to those of natural aggregates calculated with the same method $\left(D_{\mathrm{F} 1}=\right.$ $1.25 \pm 0.006$ and $\left.D_{\mathrm{F} 2}=1.86 \pm 0.015\right)$, suggesting similar fractal structure.

\section{Solid components (BSi, POC, TEP)}

The amount of BSi in aggregates increased with size with values ranging from 0.09 to $3.6 \mu \mathrm{mol}$ (Fig. 6). Values of POC and TEP in aggregates ranged from 0.28 to $13 \mu \mathrm{mol}$ and 60.5 to $488 \mu \mathrm{g} \mathrm{XG}$ equivalent, respectively. POC content in aggregates from the

Fig. 3. Sinking velocities (SV) of aggregates versus their equivalent spherical diameter (ESD) recorded at 6 stations, and theoretical expectations. (A) Stokes' law assuming a solid body with constant excess density (thick line: $\Delta \rho=$ $0.0014 \mathrm{~g} \mathrm{~cm}^{-3}, D_{\mathrm{F} 3}=3$ ) and general sinking velocity models (thin and dashed lines) for porous fractal particles with porosity scaled on size for fractal numbers of 1.2, 1.4 and 1.8 and 2 different specific conditions; $1: \mathrm{ESD}_{0}=1.5 \mathrm{~mm}, \mathrm{SV}_{0}=$ $100 \mathrm{~m} \mathrm{~d}^{-1} ; 2: \mathrm{ESD}_{0}=2 \mathrm{~mm}, \mathrm{SV}_{0}=50 \mathrm{~m} \mathrm{~d}^{-1}$. (B) Sensitivity of the general sinking velocity model to different values of coefficient a varying over 5 orders of magnitude from 0.001 to 100, for 2 fractal dimensions (dashed lines: $D_{\mathrm{F} 3}=1.8$; solid lines: $D_{\mathrm{F} 3}=1.2$ ) and one set of specific conditions: $\mathrm{ESD}_{0}=1.5$ $\mathrm{mm}, \mathrm{SV}_{0}=100 \mathrm{~m} \mathrm{~d}^{-1}$. (C) Data for each station (symbols) compared to general sinking velocity models (solid lines) with coefficient $a$ fixed at 0.01 and different $D_{\mathrm{F} 3}$ values (E-3, F-L, E-4E: $D_{\mathrm{F} 3}=1.8 ; \mathrm{A} 3-2, \mathrm{E}-5: D_{\mathrm{F} 3}=1.4 ; \mathrm{E}-4 \mathrm{~W}: D_{\mathrm{F} 3}=1.2$ ). Filled circles: specific conditions for each model ${ }_{i}$ dashed lines: best fits to data (1 outlier excluded from A3-2 fit). E-3: $y=71 x^{0.63}\left(\mathrm{n}=11, \mathrm{r}^{2}=0.49, \mathrm{p}<0.05\right) ;$ F-L: $y=53 x^{0.61}(\mathrm{n}=13$, $\left.\mathrm{r}^{2}=0.67, \mathrm{p}<0.005\right) ; \mathrm{E}-4 \mathrm{~W}: y=53 x^{-0.52}\left(\mathrm{n}=8, \mathrm{r}^{2}=0.1\right.$, $\mathrm{p}=0.46) ; \mathrm{E}-4 \mathrm{E}: y=66 \mathrm{x}^{0.62}\left(\mathrm{n}=6, \mathrm{r}^{2}=0.8, \mathrm{p}<0.05\right) ; \mathrm{A} 3-2$ : $y=36 x^{0.26}\left(\mathrm{n}=11, \mathrm{r}^{2}=0.5, \mathrm{p}=0.5\right) ; \mathrm{E}-5: y=45 x^{0.2}(\mathrm{n}=12$, $\left.r^{2}=0.4, p=0.55\right)$ 


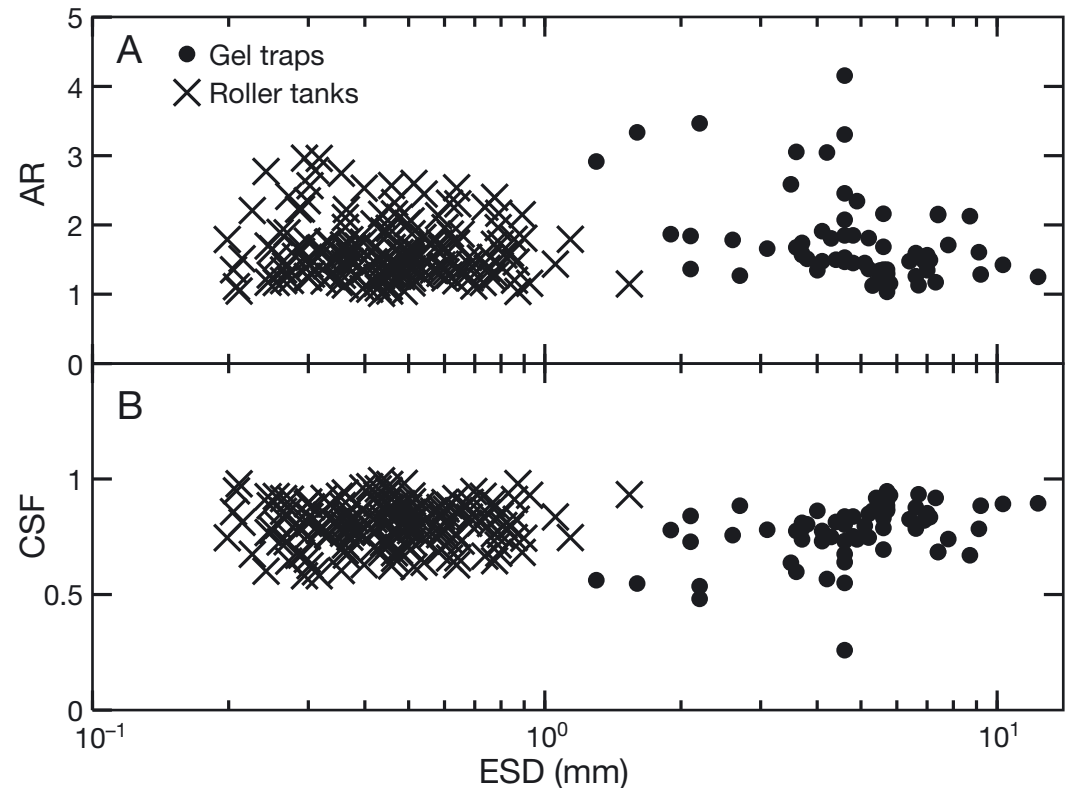

Fig. 4. Shape descriptors versus equivalent spherical diameter (ESD) for roller tank aggregates (one very long 'comet-shaped' aggregate excluded) and natural aggregates collected in polyacrylamide gel sediment traps deployed during KEOPS2. (A) Aspect ratio (AR) and (B) Corey shape factor (CSF) are in the same range of values for the 2 categories of aggregates
Stn E-4W experiment presented a high variability compared to all other experiments. TEP content did not scale with aggregate volume, possibly suggesting that only one-third of the volume of an aggregate (subsampling in $3.3 \mathrm{ml}$; see 'Materials and methods: Chemical measurements') represented a too small amount of matter to be detectable by the method used, especially for the smallest aggregates. This study aimed to obtain a complete set of chemical analyses conducted on single aggregates, which unfortunately constrained the analyses to single measurements on amounts well under the usual limits. Replicate measurements and on larger particles would have probably increased the accuracy of TEP measurements, but limited the applicability of our results to natural conditions where smaller particles dominate.
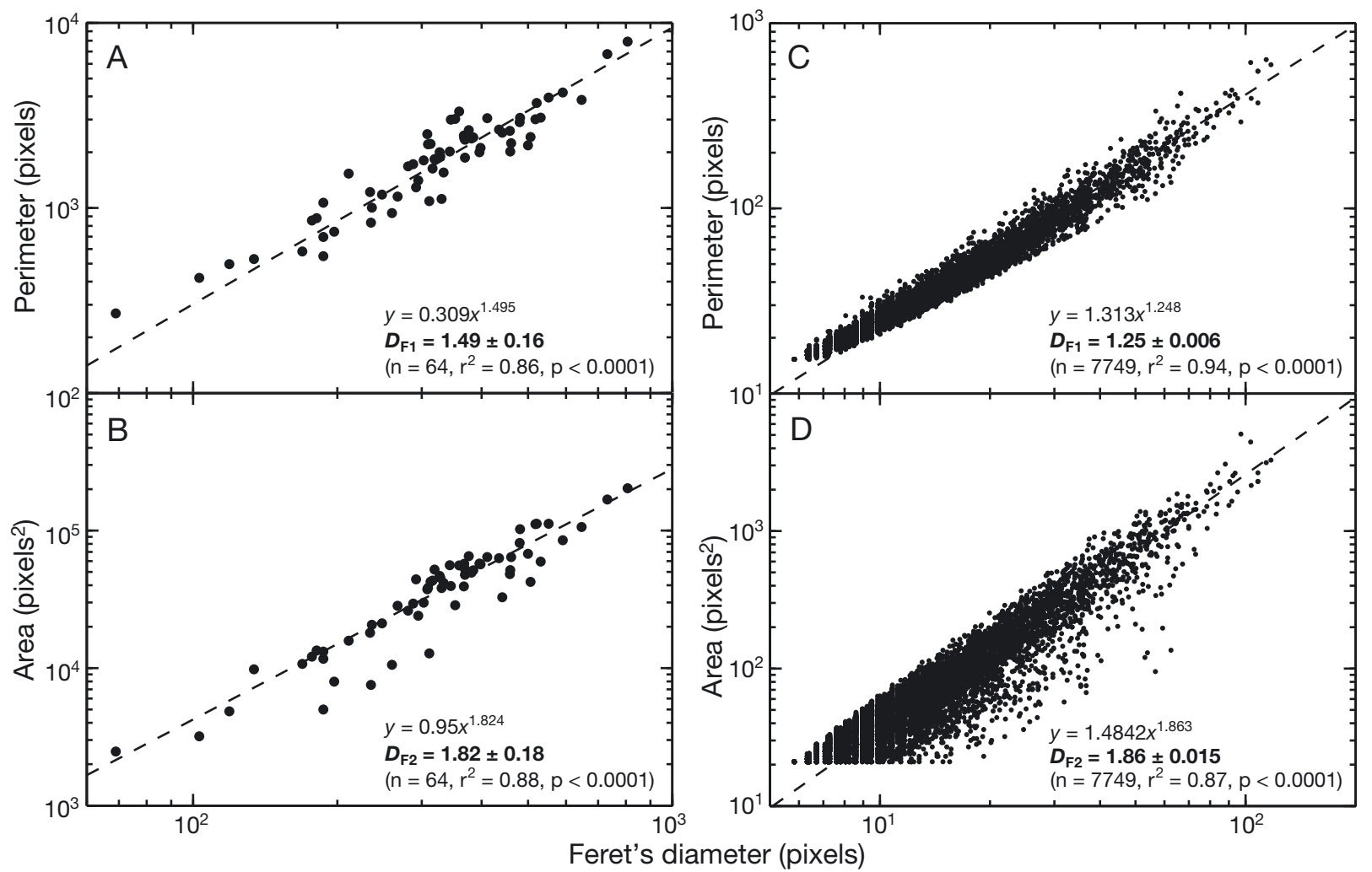

Fig. 5. Fractal numbers of (A,B) roller tank aggregates (one very long 'comet-shaped' aggregate excluded) and (C,D) natural aggregates collected in polyacrylamide gel sediment traps deployed during KEOPS2 at the same sites. 1- and 2-dimensional fractal numbers $\left(D_{\mathrm{F} 1}\right.$ and $\left.D_{\mathrm{F} 2}\right)$ : calculated from the slope of the relationships between perimeter $(\mathrm{A}, \mathrm{C})$ and area $(\mathrm{B}, \mathrm{D})$ versus their Feret's diameter. On each panel: best fit lines, fractal numbers $( \pm 95 \% \mathrm{CI})$ and regression statistics. An area cut-off at 20 pixels $^{2}$ was applied on gel trap data (visible in panel D) to exclude from the regression potential 'fake particles' deriving from small gel imperfections 


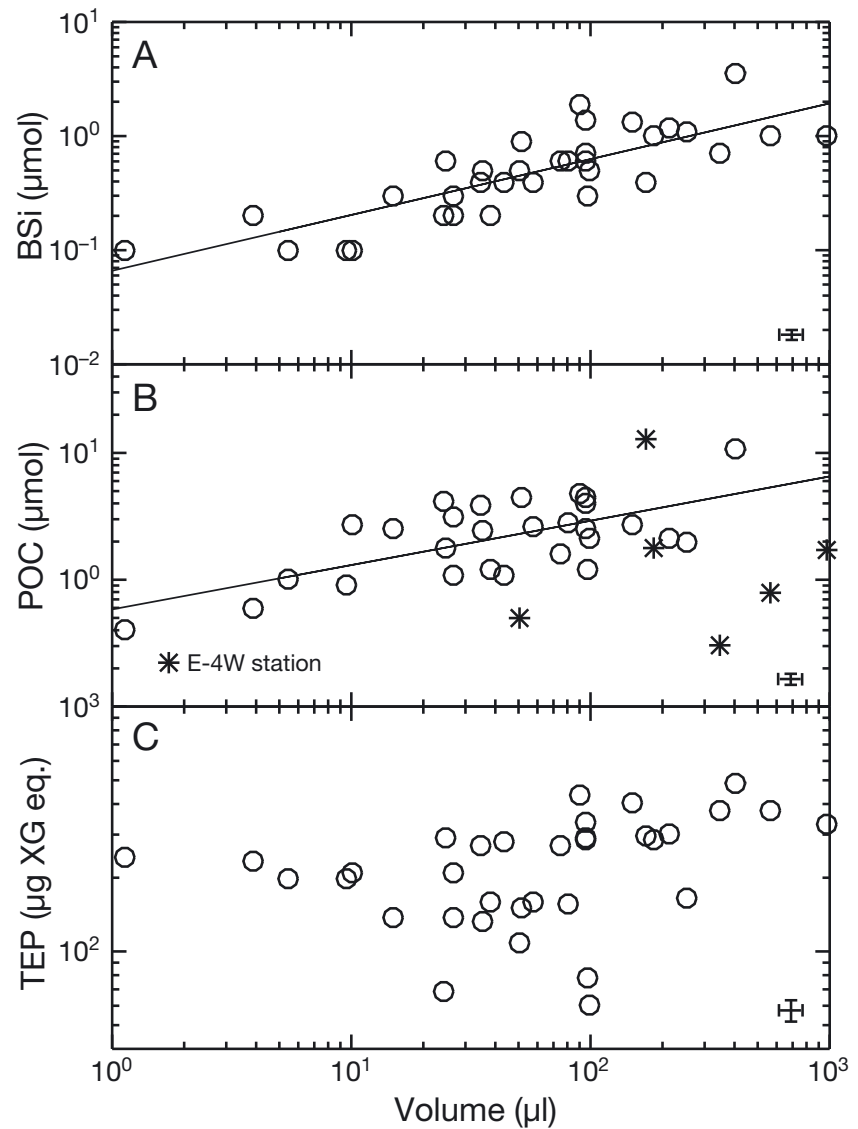

Fig. 6. Chemical component abundances in aggregates vs. volume. (A) Biogenic silica (BSi); (B) particulate organic carbon (POC); (C) transparent exopolymer particles (TEP; $\mu \mathrm{g}$ xanthan gum equivalent). Best fit lines: $\mathrm{BSi}, y=0.07 x^{0.49} ; \mathrm{n}=$ $34 ; \mathrm{r}^{2}=0.65 ; \mathrm{p}<0.0001 ;$ POC, $y=0.58 x^{0.35} ; \mathrm{n}=28 ; \mathrm{r}^{2}=0.44$; $\mathrm{p}<0.0005$. (*): scattered Stn E-4W values excluded from the fit. (O): all other data. Error bars: $10 \%$ uncertainty

\section{High-resolution pictures and phytoplankton content}

Aggregates from different sites displayed diverse aspects, colors and apparent compositions as shown in high-resolution pictures (Fig. 7). Similar observations were done on natural particles collected in polyacrylamide gel traps at the same sites. Aspects ranged from compact yellow aggregates (e.g. Fig. 7A,B \& G) to very fluffy, green and fragile aggregates (e.g. Fig. 7C,E \& H). Microscopic observations revealed distinct phytoplankton species assemblages composing the roller tank aggregates (Fig. 7J-L). The proportion and average sizes of phytoplankton cells for the main species or genera identified in the aggregates are reported in Table 2 . The largest average proportions of the total organisms counted in all aggregates in descending order were Chaetoceros subgenus Hyalochaete spp. (mean \pm SD: $27 \pm 24 \%$ ); Fragilariopsis spp. $(19 \pm 20 \%)$ including the species kerguelensis and rhombica; small centrics represented mainly by Thalassiosira spp. $(13 \pm 15 \%)$; Pseudo-nitzschia spp. $(11 \pm 7 \%)$; and Eucampia antarctica $(7 \pm 8 \%)$. The average cell diameter measured over each species ranged from $13.6 \pm 1.94$ to $91.8 \pm 23.3 \mu \mathrm{m}$. Phytoplankton classified as type 1 (see 'Materials and methods: Microscopic observations') ranged from 0.24 (Stn A3-2) to $70 \%$ (Stn E-3) of total organisms counted in aggregates. Type 2 represented 0 (Stn E-3) to $84.8 \%$ (Stn A3-2).

\section{Sinking velocity controls}

Results of the multiple regression analyses (Table 3) suggest that chemical composition and phytoplankton cell length and type predict the largest part of sinking velocity variations, overcoming the effect of aggregate size or shape. A decrease in the correlation coefficient $\left(\mathrm{r}^{2}\right)$ of 0.26 and 0.32 was induced by the removal of chemical composition and phytoplankton type terms, respectively. ANOVA F-tests revealed that models reduced from chemical composition and phytoplankton types were significantly different from the initial models $(p<0.05)$. Conversely, the removal of aggregate size terms from fits 1 and 2 led to decreases in $\mathrm{r}^{2}$ of 0.17 and 0.12 respectively. The removal of aggregate shape terms from fits 1 and 2 induced decreases of $\mathrm{r}^{2}$ of 0.09 and 0.03 respectively. None of the models reduced from size or shape terms were significantly different from the complete models.

Two additional multiple regressions were performed to identify which of chemical composition or phytoplankton types presented the best correlation to sinking velocity. This was done by removing aggregate size and shape parameters at the same time from the initial fits (Table 3 bottom row), leaving chemical composition and phytoplankton type as unique aggregate properties in fit 1 and fit 2, respectively. A better fit was obtained when sinking velocity was regressed against phytoplankton types than against chemical composition $\left(\mathrm{n}=30 ; \mathrm{r}^{2}=0.36\right.$; $\mathrm{p}<$ 0.05 , and $\mathrm{n}=31 ; \mathrm{r}^{2}=0.21 ; \mathrm{p}<0.5$, respectively).

In addition, data of shape (Corey shape factor and aspect ratio) and solid content (BSi, TEP, POM) were explored separately by site (Fig. 8A-E). Results suggest that shape and chemical composition are not site-dependent and exert no clear influence on the sinking velocity. According to our main hypothesis, 

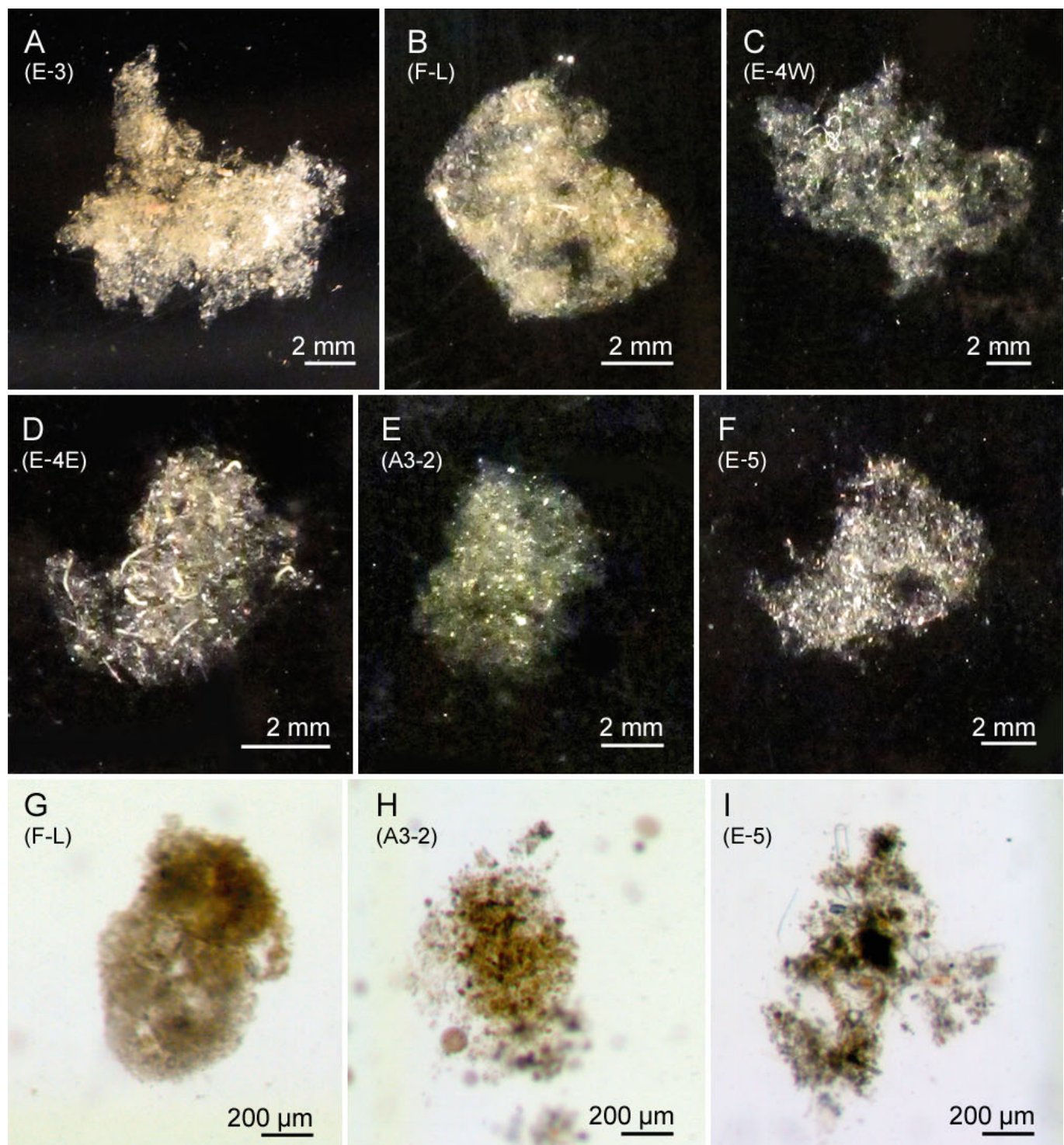

\section{$\mathrm{H}$}

(A3-2)
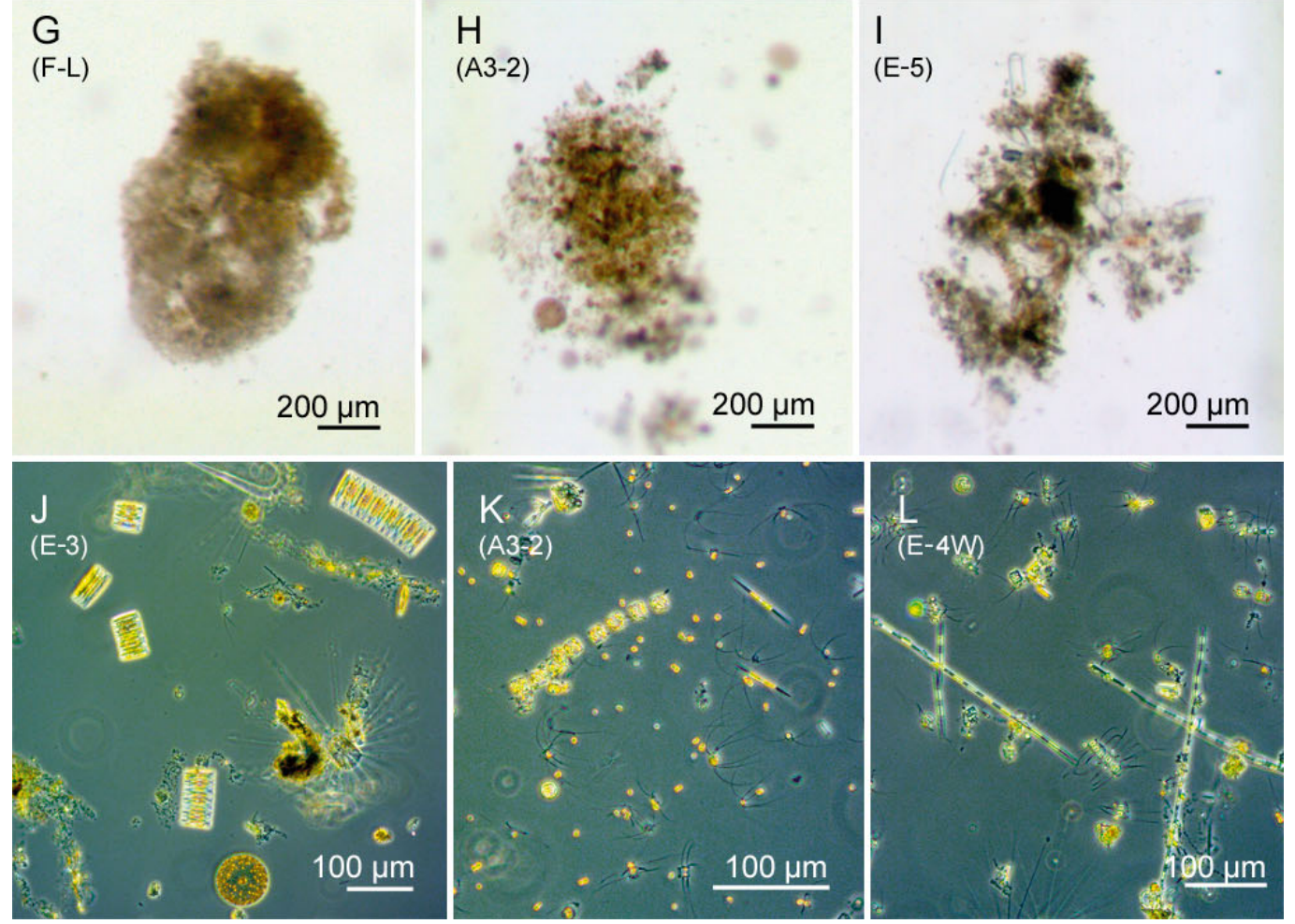

Fig. 7. Pictures of $(A-F)$ roller tank aggregates formed at each station and (G-I) natural marine snow collected in polyacrylamide gel traps at the same locations (note the similarities in aspect, shape and compactness between natural particles and those formed in roller tanks at the same sites). (J-L) Pictures showing distinct phytoplankton assemblages in roller tank aggregates from Stns E-3 (Fragilariopsis spp., Corethron pennatum and centric diatoms), A3-2 (Chaetoceros subgenus Hyalochaete spp., small centric diatoms and Pseudo-nitzschia spp.), and E-4W (Pseudo-nitzschia spp. and Chaetoceros subgenus Hyalochaete spp.), respectively 


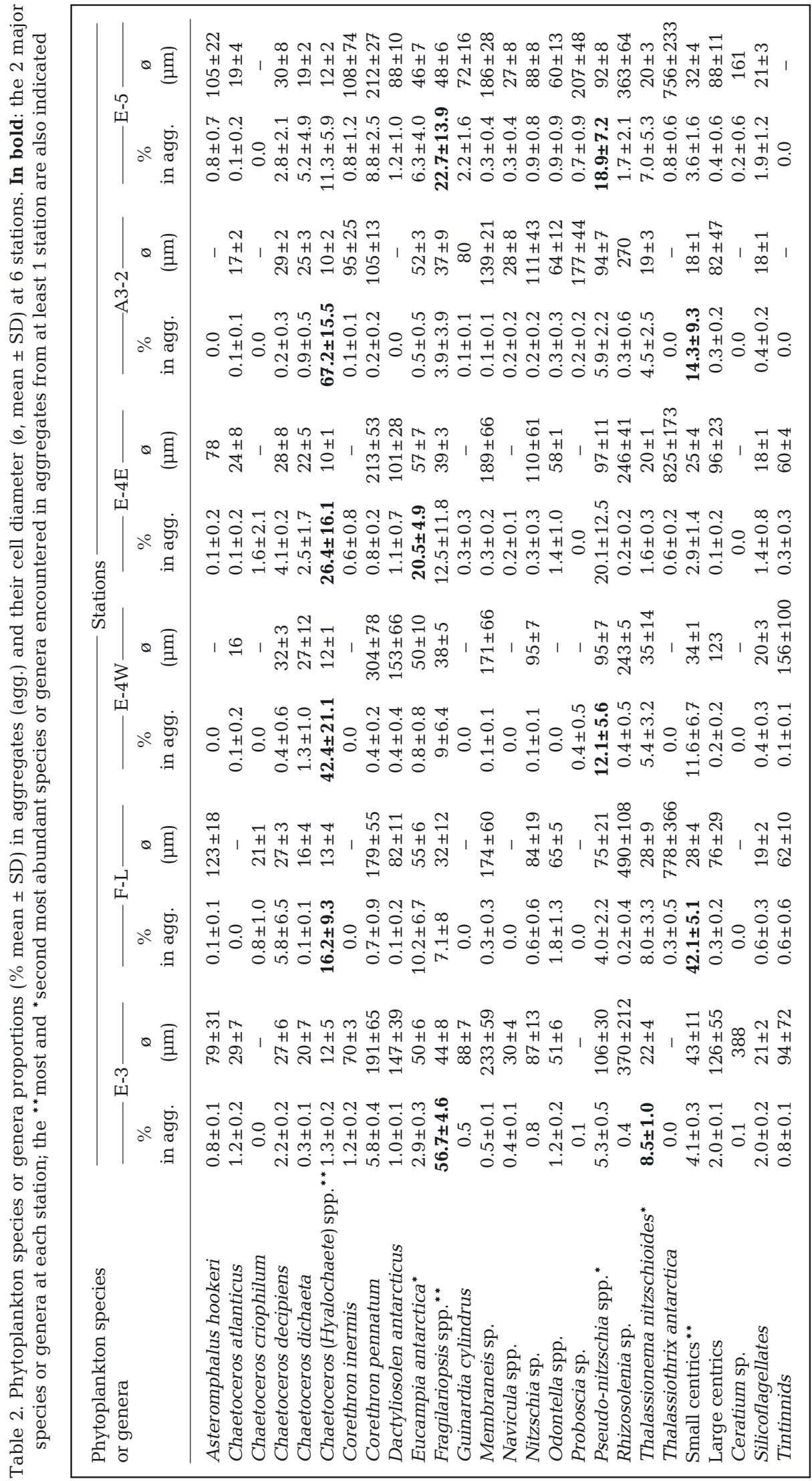


Table 3. Multiple regression analyses statistics: relative contribution of aggregate properties to sinking velocity (SV) variations. Parameters investigated: aggregate size, shape, chemical composition (BSi, POM and TEP average mass fraction in solid content) and average phytoplankton type in aggregates. New $\mathrm{r}^{2}$ and p-values (variations in parentheses) after removal of terms from the initial complete fits (1 and 2) are given. Initial and reduced models are compared by performing ANOVA F-tests. Significant modification of the initial model are in bold $(\mathrm{p}<0.05)$ and show the importance of the terms removed in sinking velocity variations. Type 1 and 2: average proportion (\%) of (1) chain diatom cells without setae and (2) small setaeforming diatom cells in aggregates, respectively. ESD: equivalent spherical diameter; CSF: Corey shape factor; AR: aspect ratio; BSi: biogenic silica; POM: particulate organic matter; TEP: transparent exopolymeric particles

\begin{tabular}{|c|c|c|c|c|c|c|}
\hline \multirow[t]{2}{*}{ Terms removed from the fit } & \multicolumn{3}{|c|}{-Fit $1-$} & \multirow{2}{*}{ New $r^{2}$} & \multicolumn{2}{|l|}{- Fit 2} \\
\hline & New $r^{2}$ & $\begin{array}{c}\text { New } \\
\text { p-value }\end{array}$ & $\begin{array}{c}F \text {-test } \\
\text { p-value }\end{array}$ & & $\begin{array}{c}\text { New } \\
\text { p-value }\end{array}$ & $\begin{array}{c}F \text {-test } \\
\mathrm{p} \text {-value }\end{array}$ \\
\hline Size (projected area, volume, ESD) & $0.25(-0.17)$ & $0.13(+0.03)$ & 0.17 & $0.38(-0.12)$ & $0.03(-0.01)$ & 0.22 \\
\hline Shape (CSF, AR) & $0.33(-0.09)$ & 0.1 & 0.25 & $0.47(-0.03)$ & $0.02(-0.02)$ & 0.51 \\
\hline Chemical composition (BSi, POM, TEP) & $0.16(-0.26)$ & $0.54(+0.44)$ & 0.03 & - & - & - \\
\hline Phytoplankton (cell length, type 1, type 2) & - & - & - & $0.18(-0.32)$ & $0.4(+0.36)$ & 0.01 \\
\hline Size + shape & $0.21(-0.21)$ & $0.15(+0.05)$ & 0.27 & $0.36(-0.14)$ & $0.01(-0.03)$ & 0.5 \\
\hline
\end{tabular}

dominant phytoplankton cell size and morphological types were further investigated as indirect controls of the sinking velocity (Fig. 8F-H). The clustering of data from each site suggested that dominant phytoplankton type was a site-dependent factor possibly influencing the sinking velocity. The cell length appeared to apply a moderate influence since aggregates where the largest cells were observed had intermediate sinking velocity (Stn E5), and aggregates sinking faster and slower than $100 \mathrm{~m} \mathrm{~d}^{-1}$ con-

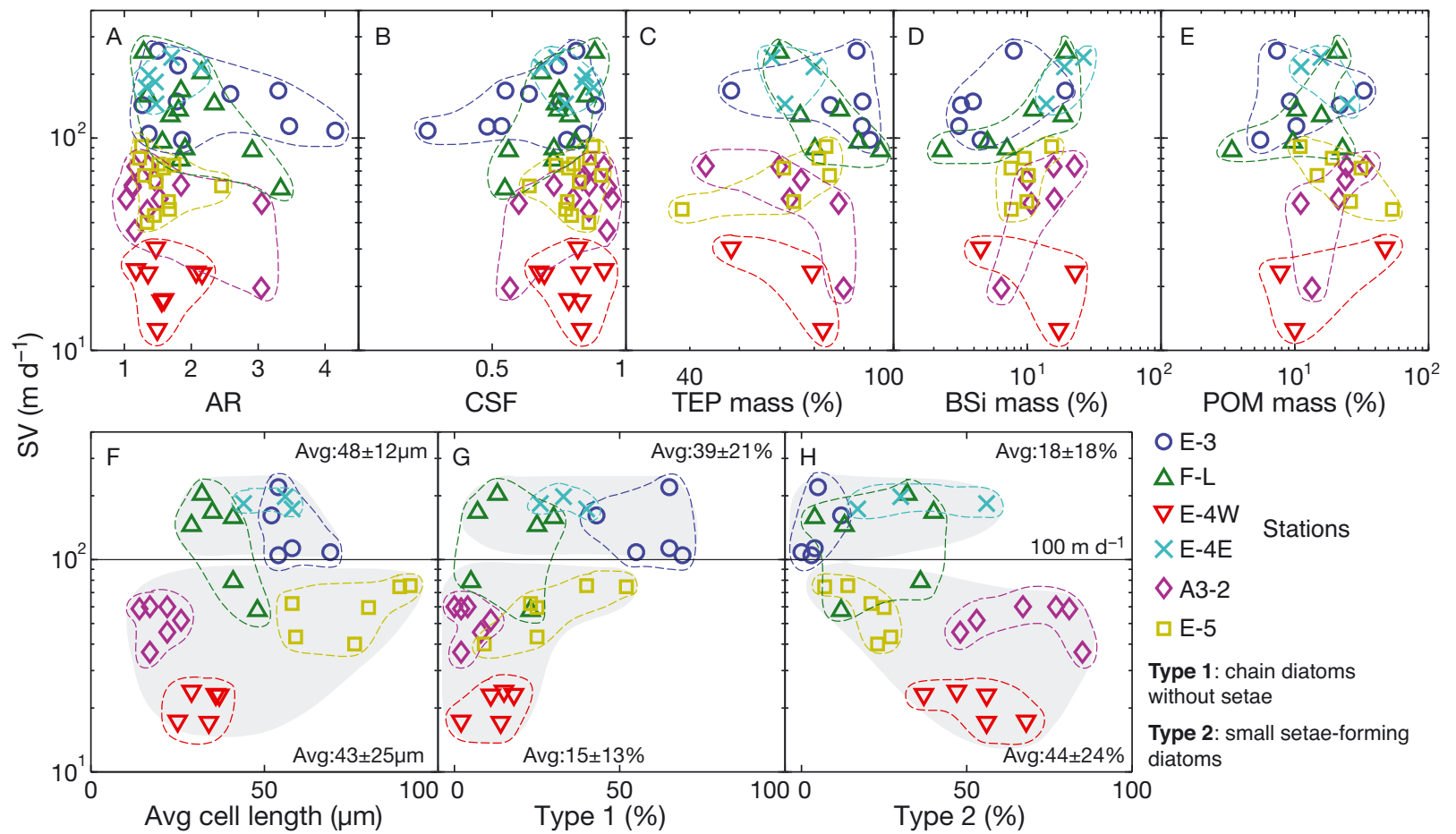

Fig. 8. Influence of shape, chemical composition and phytoplankton morphology on sinking velocity (SV). (A-E) Aspect ratio (AR), Corey shape factor (CSF), transparent exopolymer particles (TEP), biogenic silica (BSi), and particulate organic matter (POM) mass proportion in solid content, respectively. (F) Average cell length in aggregates; $(\mathrm{G}, \mathrm{H})$ proportion in aggregates of chain diatoms without setae (type 1; Fragilariopsis spp. and Eucampia antarctica) and small setae-forming diatoms (type 2; Chaeroceros spp.), respectively. There is no clear influence of shape or chemical composition. Data clustering of morphological properties of phytoplankton at each station suggests a control by phytoplankton cell type. High proportions of type 1 (39 \pm $21 \%$ ) and low proportions of type $2(18 \pm 18 \%)$ diatoms are observed in aggregates sinking faster than $100 \mathrm{~m} \mathrm{~d}^{-1}$. The opposite is found for aggregates sinking slower than $100 \mathrm{~m} \mathrm{~d}^{-1}$ (type 1: $15 \pm 13 \%$; type 2: $44 \pm 24 \%$ ) 
tained in average cells having similar length (mean \pm SD: $48 \pm 12$ and $43 \pm 25 \mu \mathrm{m}$, respectively). However, aggregates sinking faster than $100 \mathrm{~m} \mathrm{~d}^{-1}$ had high proportions of Eucampia antarctica and Fragilariopsis spp. (type 1; mean \pm SD: $39 \pm 21 \%$ ) and low proportions of Chaetoceros spp. (type $2 ; 18 \pm 18 \%$ ). In contrast, aggregates sinking slower than $100 \mathrm{~m} \mathrm{~d}^{-1}$ had low proportions of type $1(15 \pm 13 \%)$ and high proportions of type $2(44 \pm 24 \%)$.

\section{DISCUSSION}

Our image analyses suggested that the structure of aggregates produced in roller tanks were similar to those of natural aggregates collected in gel traps during KEOPS2. The fractal numbers $D_{\mathrm{F} 1}$ and $D_{\mathrm{F} 2}$ were close to those of natural particles, suggesting that aggregation processes in the roller tanks were somewhat similar to those acting in the water column. This is an encouraging result toward the applicability of this experiment to natural conditions, but needs considerable caution, especially since roller tank experiments have been previously shown to poorly simulate natural aggregation processes and should not be used for quantitative studies (Jackson 1994). Aggregates formed in the roller tanks were consistently bigger than natural aggregates collected in gel traps. One major feature of roller tank experiments which differs from natural conditions is that fast-sinking particles cannot escape from the tank and tend to form continuously larger particles until complete clearing of the water. Thus, the size of aggregates formed in roller tank experiments depends mainly on the duration of incubation. However, the main objective here was to form marine snow aggregates from a natural mixture of phytoplankton and test if variations in their composition and structure was related to sinking velocity variations. Even if aggregates formed in this experiment were far from natural particles encountered at the same sites (which does not seem to be the case according to our observations), they still can serve as model aggregates to identify factors altering the size-sinking velocity relationship.

While the overall correlation between sinking velocity and particle size is quite weak in our results, several sites exhibited reasonably tight correlations (Fig. 3C) and with slopes reasonably close to those expected from general sinking velocity models. This suggests that differences in the initial compositions might be responsible for the overall weak correlation observed when combining all aggregates from distinct sites. A match between size-sinking velocity model curves and experimental data from each site was obtained by varying the fractal dimension, indicator of particle compactness. In combination, these 2 results suggest that distinct particle sources sampled at different sites formed aggregates having different composition, structure and sinking velocity. Also, the size-sinking velocity relationship appears to be preserved for the most compact aggregates, suggesting that a reduction of the porosity could restore size as a controlling factor. Iversen \& Ploug (2010) compared size-sinking velocity relationships for different types of aggregates formed from different primary particles. They also noted a correlation of sinking velocity with size only within homogeneous sources of aggregates, but when compared across different aggregate composition, the sinking velocity appeared sizeindependent.

Overall, our results suggested a poor contribution from size, shape or chemical composition in aggregate sinking velocity variation among sites. The multiple regression analyses performed (Table 3) showed that among all the aggregate properties tested in our experiment, phytoplankton cell type seemed the best property to explain sinking velocity variation. The 2 distinct morphological categories that we selected (type 1: Eucampia antarctica and Fragilariopsis spp.; and type 2: Chaetoceros spp.) could have influenced the sinking velocity either by ballast effect (Waite et al. 1997a, Ploug et al. 2008, Iversen \& Ploug 2010, Miklasz \& Denny 2010), or by influencing aggregate structure through distinct aggregation processes. The absence of correlation between BSi mass fraction in aggregate solid content (Fig. 8D) suggests that a ballast effect did not explain a large part of sinking velocity variation; the observed increase in BSi with aggregate volume (Fig. 6), as expected for diatom aggregates, suggesting reliable measurements for this component.

Setae are known to promote phytoplankton coagulation by increasing the efficiency of 'mechanical' sticking upon contact (Alldredge \& Gotschalk 1989, Kiorboe et al. 1990). Stickiness (i.e. the probability that 2 particles become attached upon collision) has been demonstrated to be species-specific (Kiorboe et al. 1990, Alldredge et al. 1995, Crocker \& Passow 1995), and Waite et al. (1997b) noted that spine formation, cell surface bound sugars, and TEP controlled phytoplankton cell stickiness and played a role in determining aggregate structure via coagulation processes. High sticking efficiency is not subject only to cell morphology and depends on various other factors including TEP production, which plays a central role in coagulation (Kiorboe \& Hansen 1993, 
Dam \& Drapeau 1995, Jackson 1995, Thornton 2002). Cell concentration and size have also been demonstrated to be critical parameters for coagulation processes during algal blooms (Jackson 1990); high algal concentration increases the probability of encounter, and thus a high coagulation efficiency, provided that cell stickiness is sufficiently high and the cells are sufficiently large.

Logan \& Wilkinson (1990) used fractal geometry to test if colloidal aggregation mechanisms, well described for inorganic particles, were applicable to marine snow aggregates. They suggested that different types of aggregates form as a function of different particle stickiness and thus collision efficiencies. If the probability of sticking upon collision is high, cells will efficiently stick when they encounter and form highly porous and tenuous structures (diffusionlimited aggregation or DLA). In contrast, if several collisions are required, then more solid and compact aggregates are formed (reaction-limited aggregation or RLA). Meakin (1991) suggested that the processes forming marine aggregates are likely to correspond closely to the diffusion- and reaction-limited cluster-cluster aggregation mechanisms described for colloids. Aggregates formed through these 2 mechanisms may thus have distinct compactness affecting their sinking velocity.

To explore further the hypothesis that speciesspecific coagulation efficiencies were responsible for different aggregate compactness influencing the sinking velocity, we widened our morphological classification (type 1 and 2) to include the most and second most abundant phytoplankton genera in our samples (Table 2). Overall, 6 species dominated aggregate composition: Chaetoceros (Hyalochaete) spp., Pseudo-nitzschia spp., Fragilariopsis spp., E. antarctica, Thalassionema nitzschioides and small centrics. Chaetoceros (Hyalochaete) spp. was classified as type 2, along with Pseudo-nitzschia spp., (even though not producing setae) due to their morphology facilitating attachment upon collision; Fragilariopsis spp., E. antarctica, T. nitzschioides and small centric diatoms were classified as type 1. A strong linear relationship was found between the average proportion of phytoplankton cells of type 2 and the average sinking velocity recorded at each station (Fig. 9; Stn E-4E was considered an outlier, rejected at $95 \%$ confidence and excluded from the fit). In contrast to other aggregates, Stn E-4E particles contained a relatively large abundance of fecal pellets (Fig. 7D). Because fecal pellets are tightly packaged material formed by biological aggregation, this may have increased aggregate density and compactness and thus

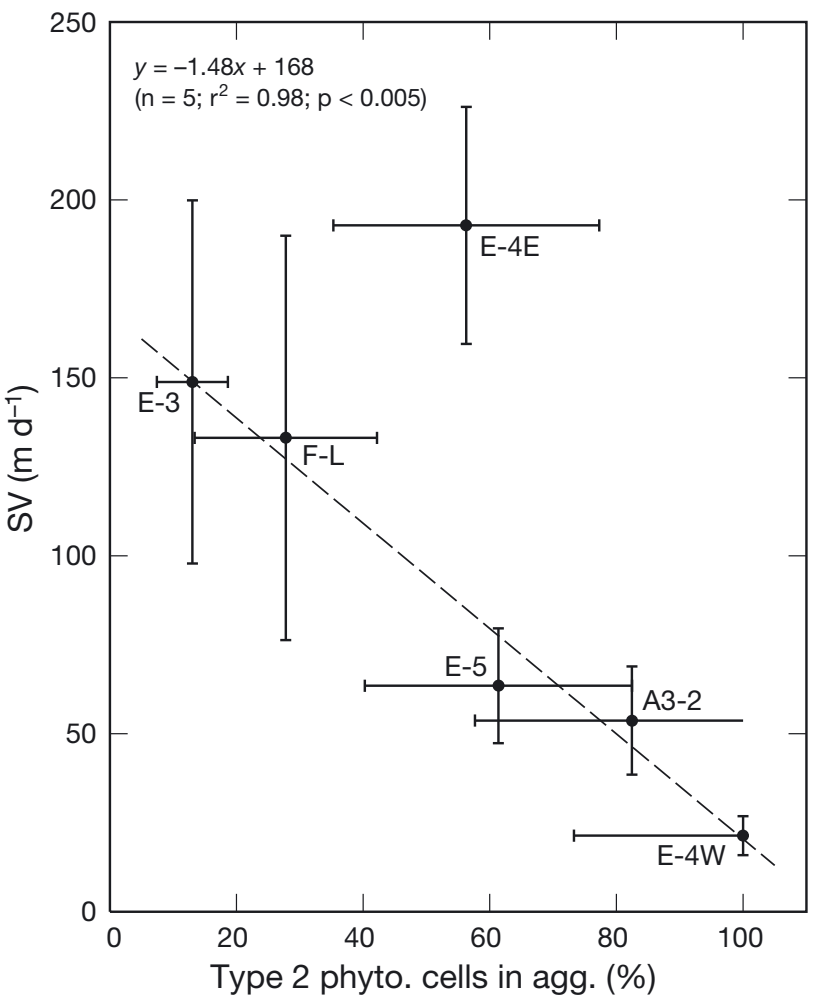

Fig. 9. Relationship between the average sinking velocity (SV) of aggregates from each station and the average proportion of phytoplankton (phyto.) cells in aggregates that had a morphology facilitating attachment upon collision (type 2; see 'Discussion'). Stn E-4E was excluded from best fit line calculation. Error bars: $1 \mathrm{SD}$

altered the relation between dominant phytoplankton types and aggregate sinking velocity. Certainly fecal pellets on their own are known to have high densities and sinking velocities (Fowler \& Small 1972, Small et al. 1979, Yoon et al. 2001). This result emphasizes the complexity of controls on the sinking velocities of marine snow and the importance of ecological considerations, suggesting that controlling factors may vary at very small spatio-temporal scales.

The variations in the dominance of the 2 phytoplankton types appears to have some relationship to biomass levels at the different stations, and perhaps to the intensity of iron fertilization. For instance, Stns A3-2 and E-4W, where the genus Chaetoceros subgenus Hyalochaete was dominant, displayed high biomass - characteristic of bloom conditions and are known to be under the influence of natural iron fertilization (Bowie et al. 2014, van der Merwe et al. 2014, Quéroué et al. 2015). Conversely, Stn E-3 was largely dominated by the ribbon-chain diatom Fragilariopsis spp. and was in a central region of moderate biomass with less iron enrichment. 
Evaluating the generality of our results will require observations on aggregates across varying levels of total biomass and ecological community structure. When comparing these environments, it is important to note that phytoplankton community composition and total biomass can have somewhat independent effects on aggregate sinking velocities; i.e. even for setae-forming species, if biomass is sufficient for aggregation to continue until very large particles are formed, then high sinking velocities can still be obtained. This could explain the EIFEX iron fertilization experiment results, during which the setaeforming diatom $C$. dichaeta was abundant, and for which transmissometry profiles were interpreted as representing $\mathrm{cm}$-sized aggregates sinking at rates $>500 \mathrm{~m} \mathrm{~d}^{-1}$ (Smetacek et al. 2012). These results are compatible with the perspectives developed here, to the extent that the very large size of the aggregates could have outweighed the expectation of low sinking velocities for aggregates formed from this species. Without any direct observations on either the aggregates or their sinking velocities during EIFEX, it is of course possible that other factors were at play, such as the myriad of influences on sinking velocities as summarized in the introduction, and the diverse nature of deep ocean particles, including living organisms (Silver \& Gowing 1991).

From a cautionary perspective, this study emphasizes that predictions of marine snow sinking velocity should not be based only on size parameterizations, and certainly should not assume that sinking velocities will always increase with size. Further studies may eventually identify those phytoplankton types which are most readily assembled into rapid sinking aggregates, by either physical or biological aggregation, as a path towards greater predictability of carbon export and biological pump efficiencies.

Acknowledgements. This work received support from the Australian Commonwealth Cooperative Research Centres Program to the ACE CRC, and the Australian National Network in Marine Science via UTAS IMAS. We thank the personnel of the RV 'Marion Dufresne', Institut Paul Emile Victor, Institut National des Sciences de l'Univers, and the KEOPS2 voyage leader Bernard Queguiner and KEOPS2 science team for assistance at sea. Stephen Bray (ACE CRC), Peter Jansen (IMOS), and David Cherry (CSIRO) prepared the free-drifting sediment trap arrays. The MODIS (NASA) satellite ocean-colour image is courtesy of Francesco d'Ovidio (Univ. Paris). The altimeter and colour/temperature products for the Kerguelen area were produced by Ssalto/Duacs and CLS with support from CNES. We thank Simon Wotherspoon (IMAS) for his precious insights into statistical analysis. We thank the 3 anonymous reviewers for their constructive and thorough comments which helped improve the manuscript.

\section{LITERATURE CITED}

Abràmoff MD, Magalhães PJ, Ram SJ (2004) Image processing with Image J. Biophot Int 11:36-42

Achenbach E (1974) The effects of surface roughness and tunnel blockage on the flow past spheres. J Fluid Mech 65:113-125

Alldredge AL, Gotschalk C (1988) In situ settling behavior of marine snow. Limnol Oceanogr 33:339-351

Alldredge AL, Gotschalk CC (1989) Direct observations of the mass flocculation of diatom blooms: characteristics, settling velocities and formation of diatom aggregates. Deep-Sea Res A 36:159-171

Alldredge AL, Gotschalk CC (1990) The relative contribution of marine snow of different origins to biological processes in coastal waters. Cont Shelf Res 10:41-58

Alldredge AL, Silver MW (1988) Characteristics, dynamics and significance of marine snow. Prog Oceanogr 20:41-82

Alldredge AL, Gotschalk C, Passow U, Riebesell U (1995) Mass aggregation of diatom blooms: insights from a mesocosm study. Deep-Sea Res II 42:9-27

Alldredge AL, Passow U, Haddock HD (1998) The characteristics and transparent exopolymer particle (TEP) content of marine snow formed from thecate dinoflagellates. J Plankton Res 20:393-406

Anderson LA (1995) On the hydrogen and oxygen content of marine phytoplankton. Deep-Sea Res I 42:1675-1680

Armstrong RA, Lee C, Hedges JI, Honjo S, Wakeham SG (2001) A new, mechanistic model for organic carbon fluxes in the ocean based on the quantitative association of POC with ballast minerals. Deep-Sea Res II 49:219-236

Asper VL, Deuser WG, Knauer GA, Lohrenz SE (1992) Rapid coupling of sinking particle fluxes between surface and deep ocean waters. Nature 357:670-672

Azetsu-Scott K, Johnson BD (1992) Measuring physical characteristics of particles: a new method of simultaneous measurement for size, settling velocity and density of constituent matter. Deep-Sea Res A 39:1057-1066

Azetsu-Scott K, Passow U (2004) Ascending marine particles: significance of transparent exopolymer particles (TEP) in the upper ocean. Limnol Oceanogr 49:741-748

Baba J, Komar PD (1981) Settling velocities of irregular grains at low Reynolds numbers. J Sediment Res 51:121-128

Batchelor GK (1967) An introduction to fluid dynamics. Cambridge University Press, Cambridge

Bienfang PK, Harrison PJ, Quarmby LM (1982) Sinking rate response to depletion of nitrate, phosphate and silicate in four marine diatoms. Mar Biol 67:295-302

Blain S, Queguiner B, Armand L, Belviso S and others (2007) Effect of natural iron fertilization on carbon sequestration in the Southern Ocean. Nature 446:1070-1074

> Bowie AR, van der Merwe P, Quéroué F, Trull T and others (2014) Iron budgets for three distinct biogeochemical sites around the Kerguelen archipelago (Southern Ocean) during the natural fertilisation experiment KEOPS-2. Biogeosci Discuss 11:17861-17923

Boyd P, Newton P (1995) Evidence of the potential influence of planktonic community structure on the interannual variability of particulate organic carbon flux. Deep-Sea Res I 42:619-639

> Boyd PW, Sherry ND, Berges JA, Bishop JKB and others (1999) Transformations of biogenic particulates from the pelagic to the deep ocean realm. Deep-Sea Res II 46: 2761-2792

> Buesseler KO (1998) The decoupling of production and particulate export in the surface ocean. Global Biogeochem Cycles 12:297-310 
Burd AB, Jackson GA (2009) Particle aggregation. Annu Rev Mar Sci 1:65-90

Carder KL, Steward RG, Betzer PR (1982) In situ holographic measurements of the sizes and settling rates of oceanic particulates. J Geophys Res 87:5681-5685

Chhabra RP (1995) Wall effects on free-settling velocity of non-spherical particles in viscous media in cylindrical tubes. Powder Technol 85:83-90

Corey A (1949) Influence of shape on the fall velocity of sand grains. MSc thesis, Colorado A \& M College, Fort Collins, $\mathrm{CO}$

Crocker KM, Passow U (1995) Differential aggregation of diatoms. Mar Ecol Prog Ser 117:249-257

$>$ Dam HG, Drapeau DT (1995) Coagulation efficiency, organicmatter glues and the dynamics of particles during a phytoplankton bloom in a mesocosm study. Deep-Sea Res II 42:111-123

de Baar HJW, de Jong JTM, Bakker DCE, Loscher BM, Veth C, Bathmann U, Smetacek V (1995) Importance of iron for plankton blooms and carbon dioxide drawdown in the Southern Ocean. Nature 373:412-415

> De La Rocha C, Passow U (2007) Factors influencing the sinking of POC and the efficiency of the biological carbon pump. Deep-Sea Res II 54:639-658

$>$ Diercks AR, Asper VL (1997) In situ settling speeds of marine snow aggregates below the mixed layer: Black Sea and Gulf of Mexico. Deep-Sea Res I 44:385-398

> Dietrich WE (1982) Settling velocity of natural particles. Water Resour Res 18:1615-1626

> Ebersbach F, Trull TW (2008) Sinking particle properties from polyacrylamide gels during the KErguelen Ocean and Plateau compared Study (KEOPS): zooplankton control of carbon export in an area of persistent natural iron inputs in the Southern Ocean. Limnol Oceanogr 53: 212-224

> Engel A, Schartau M (1999) Influence of transparent exopolymer particles (TEP) on sinking velocity of Nitzschia closterium aggregates. Mar Ecol Prog Ser 182:69-76

Engel A, Szlosek J, Abramson L, Liu Z, Lee C (2009) Investigating the effect of ballasting by $\mathrm{CaCO}_{3}$ in Emiliania huxleyi: I. Formation, settling velocities and physical properties of aggregates. Deep-Sea Res II 56:1396-1407

> Fowler SW, Knauer GA (1986) Role of large particles in the transport of elements and organic compounds through the oceanic water column. Prog Oceanogr 16:147-194

Fowler SW, Small LF (1972) Sinking rates of euphausiid fecal pellets. Limnol Oceanogr 17:293-296

Gehlen M, Bopp L, Emprin N, Aumont O, Heinze C, Ragueneau O (2006) Reconciling surface ocean productivity, export fluxes and sediment composition in a global biogeochemical ocean model. Biogeosciences 3:521-537

Gibbs RJ (1985) Estuarine flocs: their size, settling velocity and density. J Geophys Res 90:3249-3251

Graf WH, Acaroglu ER (1966) Settling velocities of natural grains. Hydrol Sci J 11:27-43

Guidi L, Jackson GA, Stemmann L, Miquel JC, Picheral M, Gorsky G (2008) Relationship between particle size distribution and flux in the mesopelagic zone. Deep-Sea Res I 55:1364-1374

Iversen $\mathrm{MH}$, Ploug $\mathrm{H}$ (2010) Ballast minerals and the sinking carbon flux in the ocean: carbon-specific respiration rates and sinking velocity of marine snow aggregates. Biogeosciences 7:2613-2624

Jackson GA (1990) A model of the formation of marine algal flocs by physical coagulation processes. Deep-Sea Res I 37:1197-1211

> Jackson GA (1994) Particle trajectories in a rotating cylin- der: implications for aggregation incubations. Deep-Sea Res I 41:429-437

Jackson GA (1995) TEP and coagulation during a mesocosm experiment. Deep-Sea Res II 42:215-222

Jackson GA (1998) Using fractal scaling and two-dimensional particle size spectra to calculate coagulation rates for heterogeneous systems. J Colloid Interface Sci 202: 20-29

Jannasch HW, Zafiriou OC, Farrington JW (1980) A sequencing sediment trap for time-series studies of fragile particles. Limnol Oceanogr 25:939-943

Johnson CP, Li X, Logan BE (1996) Settling velocities of fractal aggregates. Environ Sci Technol 30:1911-1918

Jouandet MP, Trull TW, Guidi L, Picheral M, Ebersbach F, Stemmann L, Blain S (2011) Optical imaging of mesopelagic particles indicates deep carbon flux beneath a natural iron-fertilized bloom in the Southern Ocean. Limnol Oceanogr 56:1130-1140

Kajihara M (1971) Settling velocity and porosity of large suspended particle. J Oceanogr Soc Jpn 27:158-162

Karl DM, Knauer GA, Martin JH (1988) Downward flux of particulate organic matter in the ocean: a particle decomposition paradox. Nature 332:438-441

> Kilps JR, Logan BE, Alldredge AL (1994) Fractal dimensions of marine snow determined from image analysis of in situ photographs. Deep-Sea Res I 41:1159-1169

> Kiorboe T, Hansen JLS (1993) Phytoplankton aggregate formation: observations of patterns and mechanisms of cell sticking and the significance of exopolymeric material. J Plankton Res 15:993-1018

- Kiorboe T, Andersen K, Dam H (1990) Coagulation efficiency and aggregate formation in marine phytoplankton. Mar Biol 107:235-245

> Klaas C, Archer DE (2002) Association of sinking organic matter with various types of mineral ballast in the deep sea: implications for the rain ratio. Global Biogeochem Cycles 16:1116

> Komar PD, Reimers C (1978) Grain shape effects on settling rates. J Geol 86:193-209

- Kriest I, Oschlies A (2008) On the treatment of particulate organic matter sinking in large-scale models of marine biogeochemical cycles. Biogeosciences 5:55-72

- Kriest I, Oschlies A (2013) Swept under the carpet: organic matter burial decreases global ocean biogeochemical model sensitivity to remineralization length scale. Biogeosciences 10:8401-8422

> Laurenceau EC, Trull TW, Davies DM, Bray SG and others (2014) The relative importance of phytoplankton aggregates and zooplankton fecal pellets to carbon export: insights from free-drifting sediment trap deployments in naturally iron-fertilised waters near the Kerguelen plateau. Biogeosci Discuss 11:13623-13673

Li XY, Logan BE (2001) Permeability of fractal aggregates. Water Res 35:3373-3380

Li XY, Yuan Y (2002) Settling velocities and permeabilities of microbial aggregates. Water Res 36:3110-3120

Logan BE, Wilkinson DB (1990) Fractal geometry of marine snow and other biological aggregates. Limnol Oceanogr 35:130-136

Losch M, Strass V, Cisewski B, Klaas C, Bellerby RGJ (2014) Ocean state estimation from hydrography and velocity observations during EIFEX with a regional biogeochemical ocean circulation model. J Mar Syst 129:437-451

Martin JH (1990) Glacial-interglacial $\mathrm{CO}_{2}$ change: the iron hypothesis. Paleoceanography 5:1-13

Martin JH, Knauer GA, Karl DM, Broenkow WW (1987) VERTEX: carbon cycling in the northeast Pacific. Deep- 
Sea Res A 34:267-285

Martin P, Lampitt RS, Jane Perry M, Sanders R, Lee C, D'Asaro E (2011) Export and mesopelagic particle flux during a North Atlantic spring diatom bloom. Deep-Sea Res I 58:338-349

Matsumoto K, Suganuma A (1977) Settling velocity of a permeable model floc. Chem Eng Sci 32:445-447

McCave IN (1984) Size spectra and aggregation of suspended particles in the deep ocean. Deep-Sea Res A 31: 329-352

McDonnell AMP, Buesseler KO (2010) Variability in the average sinking velocity of marine particles. Limnol Oceanogr 55:2085-2096

McNown JS, Malaika J (1950) Effects of particle shape on settling velocity at low Reynolds numbers. Trans Am Geophys Union 31:74-82

Meakin P (1991) Fractal aggregates in geophysics. Rev Geophys 29:317-354

Miklasz KA, Denny MW (2010) Diatom sinking speeds: improved predictions and insight from a modified Stokes' law. Limnol Oceanogr 55:2513-2525

Muggli DL, Lecourt M, Harrison PJ (1996) Effects of iron and nitrogen source on the sinking rate, physiology and metal composition of an oceanic diatom from the subarctic Pacific. Mar Ecol Prog Ser 132:215-227

Nowald N, Fischer G, Ratmeyer V, Iversen M, Reuter C, Wefer G (2009) In situ sinking speed measurements of marine snow aggregates acquired with a settling chamber mounted to the Cherokee ROV. In: OCEANS 2009Europe, 11-14 May 2009, Bremen, Germany, Vol 2. IEEE Proceedings CFPO90CF-PRT, p 1286-1291

> Padisák J, Soróczki-Pintér É, Rezner Z (2003) Sinking properties of some phytoplankton shapes and the relation of form resistance to morphological diversity of planktonan experimental study. Hydrobiologia 500:243-257

Passow U (1991) Species-specific sedimentation and sinking velocities of diatoms. Mar Biol 108:449-455

Passow U (2012) The abiotic formation of TEP under different ocean acidification scenarios. Mar Chem 128-129:72-80

- Passow U, Alldredge AL (1995) A dye-binding assay for the spectrophotometric measurement of transparent exopolymer particles (TEP). Limnol Oceanogr 40:1326-1335

> Passow U, De La Rocha CL (2006) Accumulation of mineral ballast on organic aggregates. Global Biogeochem Cycles 20:GB002579, doi:10.1029/2005GB002579

Ploug H, Iversen MH, Fischer G (2008) Ballast, sinking velocity, and apparent diffusivity within marine snow and zooplankton fecal pellets: implications for substrate turnover by attached bacteria. Limnol Oceanogr 53: 1878-1886

> Ploug H, Terbruggen A, Kaufmann A, Wolf-Gladrow D, Passow U (2010) A novel method to measure particle sinking velocity in vitro, and its comparison to three other in vitro methods. Limnol Oceanogr Methods 8:386-393

Quéroué F, Sarthou G, Planquette HF, Bucciarelli E and others (2015) High variability of dissolved iron concentrations in the vicinity of Kerguelen Island (Southern Ocean). Biogeosci Discuss 12:231-270

> Ragueneau O, Savoye N, Del Amo Y, Cotten J, Tardiveau B, Leynaert A (2005) A new method for the measurement of biogenic silica in suspended matter of coastal waters: using $\mathrm{Si}$ :Al ratios to correct for the mineral interference. Cont Shelf Res 25:697-710

Reynolds O (1883) An experimental investigation of the circumstances which determine whether the motion of water shall be direct or sinuous, and of the law of resistance in parallel channels. Philos Trans R Soc Lond 174:
935-982

Savoye N, Trull TW, Jacquet SHM, Navez J, Dehairs F (2008) ${ }^{234} \mathrm{Th}$-based export fluxes during a natural iron fertilization experiment in the Southern Ocean (KEOPS). Deep-Sea Res II 55:841-855

Shanks AL, Edmondson EW (1989) Laboratory-made artificial marine snow: a biological model of the real thing. Mar Biol 101:463-470

- Shanks AL, Trent JD (1980) Marine snow: sinking rates and potential role in vertical flux. Deep-Sea Res A 27:137-143

Sigman DM, Boyle EA (2000) Glacial/interglacial variations in atmospheric carbon dioxide. Nature 407:859-869

- Silver MW, Gowing MM (1991) The 'particle' flux: origins and biological components. Prog Oceanogr 26:75-113

Small LF, Fowler SW, Ünlü MY (1979) Sinking rates of natural copepod fecal pellets. Mar Biol 51:233-241

Smetacek V, Klaas C, Strass VH, Assmy P and others (2012) Deep carbon export from a Southern Ocean iron-fertilized diatom bloom. Nature 487:313-319

> Stemmann L, Jackson G, Gorsky G (2004) A vertical model of particle size distributions and fluxes in the midwater column that includes biological and physical processes Part II: application to a three year survey in the NW Mediterranean Sea. Deep-Sea Res I 51:885-908

Stokes GG (1851) On the effect of the internal friction of fluids on the motion of pendulums. Trans Camb Philos Soc 9:8-106

Suess E (1980) Particulate organic carbon flux in the oceans - surface productivity and oxygen utilization. Nature 288:260-263

> Sullivan CW, Arrigo KR, McClain CR, Comiso JC, Firestone J (1993) Distributions of phytoplankton blooms in the Southern Ocean. Science 262:1832-1837

> Syvitski JPM, Asprey KW, Leblanc KWG (1995) In situ characteristics of particles settling within a deep-water estuary. Deep-Sea Res II 42:223-256

Thornton DCO (2002) Diatom aggregation in the sea: mechanisms and ecological implications. Eur J Phycol 37: $149-161$

van der Merwe P, Bowie AR, Quéroué F, Armand L and others (2014) Sourcing the iron in the naturally-fertilised bloom around the Kerguelen Plateau: particulate trace metal dynamics. Biogeosci Discuss 11:13389-13432

Volk T, Hoffert MI (1985) Ocean carbon pumps: analysis of relative strengths and efficiencies in ocean-driven atmospheric $\mathrm{CO}_{2}$ changes. In: Sundquist ET, Broecker WS (eds) The carbon cycle and atmospheric $\mathrm{CO}_{2}$ : natural variations Archean to Present, Vol 32. AGU, Washington, DC, p 99-110

- Waite AM, Thompson PA, Harrison PJ (1992) Does energy control the sinking rates of marine diatoms? Limnol Oceanogr 37:468-477

Waite A, Fisher A, Thompson PA, Harrison PJ (1997a) Sinking rate versus cell volume relationships illuminate sinking rate control mechanisms in marine diatoms. Mar Ecol Prog Ser 157:97-108

Waite A, Gallager S, Dam H (1997b) New measurements of phytoplankton aggregation in a flocculator using videography and image analysis. Mar Ecol Prog Ser 155:77-88

White FM (1974) Viscous fluid flow. McGraw-Hill, New York, NY

Williams GP (1966) Particle roundness and surface texture effects on fall velocity. J Sediment Res 36:255-259

Yoon W, Kim S, Han K (2001) Morphology and sinking velocities of fecal pellets of copepod, molluscan, euphausiid, and salp taxa in the northeastern tropical Atlantic. Mar Biol 139:923-928 